\title{
Tadeusz Kruszyński
}

\section{Znaczenie wyrazu prawo w jezyku staropolskim i ludowych gwarach}

Prawo Kanoniczne : kwartalnik prawno-historyczny 1/1-2, 343-377

1958

Artykuł został zdigitalizowany i opracowany do udostępnienia w internecie przez Muzeum Historii Polski w ramach prac podejmowanych na rzecz zapewnienia otwartego, powszechnego i trwałego dostępu do polskiego dorobku naukowego i kulturalnego. Artykuł jest umieszczony w kolekcji cyfrowej bazhum.muzhp.pl, gromadzącej zawartość polskich czasopism humanistycznych i społecznych.

Tekst jest udostępniony do wykorzystania w ramach dozwolonego użytku. 


\title{
SPRAWOZDANIA - RECENZJE - KOMUNIKATY
}

\author{
KS. TADEUSZ KRUSZY KSKI
}

\section{ZNACZENIE WYRAZU PRAWO W JEZZYKU STAROPOLSKIM I LUDOWYCH GWARACH}

Prawować się $w$ znaczeniu procesować się, litigare, se judicare, praesidere, agere.

W Summie Głównej Statutów Kazimierza Wielkiego w tłomaczeniu magistra i dolstora ks. Swiętosława $z$ Wocieszyna (Starodawne Prawa Polskiego Pomniki. wyd. A. Z. Helcel T. I. WarszawaKraków. 1856. str. 17. LII.): „Z pospolitym młynarzem alibo sługa jeden brat może o krzywdę przed obranym Sędzią sądzić i prawowač: „Poterit se pro injuria coram judice electo judicare”. Tamże na str. 57. XII: „Urząd takie zwania prawujące się przed sędzie ku prawu, tako ustawiamy być popisany": „Ordinem autem vocandi ipsos litigantes, ad praesentiam ipsorum judicum, taliter duximus describendum;... podlug oczredzy się prawujących": „Secundum ordinem litigantium".

$\mathrm{Z}$ akt wielkopolskich $\mathrm{z}$ 1400. roku (J. Leks z y k i: Die ältesten grosspolnischen Grodbücher. II, Lipzbig. 1887-1889. Publicationen aus den Preussischen Staatsarchiven. Nr 992.): „Helska odpusczila Boguslawowi o ti kone i to, czso szą s nym pravovala".

W rękopisie Biblioteki Jagiellońskiej, $\mathrm{Nr}$ 2503. z około 1428, roku (Lucjan Malinowski: Zabytki języka polskiego: Prace Filol. Warszawa. I. 488.): „agerent - prawowaly sze".

W mamotrekcie kaliskim wraz $\mathrm{z}$ wariantami mamotrektu lubinskiego z 1471. roku (Ja n Éoś: Materiały i Prace Kom. Językowej A. U. V. 50.): „Prawowacz bandzie (będzie), praesidebit”, tamże: „Dobrze swą czeladz prawge, bene prepositum". Tu praesidium i praesidere użyte $w$ znaczeniu obrony i bronienia się.

W Ortylach Magdeburskich, czyli wyrokach sasdu miejskiego, pochodzących z połowy XV. wieku (A 1. B r ückner: Die Magdeburger Urtheile: Archiv für slavische Philologie. V. Jagić. Berlin. VI. 338.): "O prawowanym besz prawnych rzeczy". Tamże (VII. 573.):

"Poczatek artykutu w „Polonia Sacra” r. 1958, Nr 2. 
„Nathego mayą prawowacz". W tychże, wedle innego wydania (W. A. M a c i e jow s ki: Historia Prawodawstw Słowiańskich. T. VI. Warszawa, 1858. str. 31. Nr. XXII.): „Thego mayą poszwacz (pozwać) przed prawo... a prawowacz szye sznym, aby szaszye (zasię) odpowyedzal”. Tamże (Str. 51. Nr. LXIIII.): „Dwe rodzonye szestrze... przyszly, a mlodsza szye prawowala na sztarszą, oyczyszny y macierzyszny" (tj. o majątek matczyny i ojcowsiki). Tamże (str. 58. Nr. LXXXXVI.): „Gdy woyth albo przyszyasznyczy szyedza ku praw, a sządu nie gayą, any zadny sząd sztara dawnego (starodawnego) obyczaya gagyaly, ale thako przesz gayneigo sządu (zebranego sądu) przed nymy szye prawowano, a any thako sządzyly y szwyadczyly". Tamże (str. 123, Nr. CCXXVII.): „Pothym przyida (przyjdą) dwa o thaką rzecz prawowacz". Tamże (str. 126. Nr. CCXXXII.): „Prawowalaszta szye dwa o murowana sczyanę".

Wiadomość $z$ okołu 1500. roku (E mil K ał użnicki: Kleinere altpolnische Texte aus Handschriften des XV. und des Anfangs des XVI. Jahrhunderts: Sitzungsberichte der philosophisch-historischen Classe d. Kais. Akademie der Wissenschaften. CI. Wien. 1882, 180.): „Gdyby czlowyek zapowyedzal $w$ gymyenye (gminie), czo by doma nye byl, a kako dlugo (jak długo) doma szą prawował, az by go prawem dobyl,... proszymy wasz, nauczczye nasz".

W glosach polskich wpisanych nieco później do łacińsko-niemieckiego słownika, wydanego $w$ 1490. roku (Bolesław Erzepki: Przyczynki do średniowiecznego slownictwa polskiego: Roczniki Tow. Przyj. Nauk Poznańskiego. T. XXXIV. 77.): „Agerent - pravovaly szya".

Tego wyrażenia użył Marcin Bielski w. swej „Kronice Swiata" Kraków, 1564. 210, v.: Także w Spirze uczyniono postanowienie, yż niektore prawa uczynione na Sędzie, niektore na Woyty, niektore na ty co się prawuia, gdy to Cesarzowi ukazano, podobalo sie mu to"; 239. v.: $W$ sprawie o biskupstwo mediolańskie: „Gdy się prawowali przed Papieżem o nie".

Stanisław Orzechowski w dziale z 1563, roku: „Rozmowa albo Dyalog około Exekucyey Polskiey Korony", wyraził się na str. L4v. „Nie będzieć to Królu, w tym cię słuchać niebędziemy, musić to być inak: otworem nam stoi poksoy Krolewski, prawuiemy sye przed Krolem swym wolnie".

Łukasz Górnicki w sławnyim dziele „Dworzanin” pisał na str. 179: „Rzadko to jest, aby się biegły w prawie, prawowal”.

Wyrażenie „prawowac się" utrzymało się w gwarach ludowych nietylko w Zywieckiem, Krakowskiem i Kieleakiem, ale i w Wielkopolsce i na Poidlasiu, a nawet na Kaszubach, w znaczeniu: dochodzić 
sprawiedliwości, procesować się. Jedynie na Skalnym Podhalu i na Spiszu mówią „prawocić się”. N.p.; „Cyk (tj. czym) się nie prawocil bez półcwarta roku pokrony (tj. spowodu) tego gruntu po cioce?" czyli: „czy nie procesowałem się przez półczwarta roku z powrodu tego pola po ciotce?" (Kazimierz Tetmajer: Na skalnem Podhalu, Kraków. 1914. 108): Dalej: „Kieby ci wej fto takom skode zrobiel, kielobyś naikłaidal na prawo (wydał na proces) ale sie wej z $\mathrm{Pa}$ nem Jezusem nie bedzies prawocił, ani pudzies ś nim bić". (,Lud" XVI. 303.) „Góral gidy sie prawoci, przechowuje starannie papiery". (WIadysıaw Matlakowski: Zdobienie i sprzęt ludu polskiego na Podhalu. Warszawa. 1901. 80.): „Abo by sie prawocil" ("Lud". XVI. 295.): „Prawocić się nie prawocil, po urzędak (urzędach) po próżnicy nie chodzieł", (Tamże: XVI. 400.). Z Czarnego Dunajca: „Przeprawocić majątek. Jak sie bees cięgiem prawocił, stracis na procesy majątek". (Ja n Ka ntor: Czarny Dunajec: Materiały Antropol. Archeol. i Etnogr. A. U. IX. 213.). Z Trybszu na Spiszu: „Ale sie cuowiek niefce prawocić", (Kazimierz Nitsch: Wybór Polskich telkstów gwarowych: Biblioteka Slawistyczna. Lwów. 1929. 52. Nr. 45.). „Prawocić się" mówią jeszcze w Niedźwiedziu, czyli Porębie Wielkiej, w Gorcach nad Mszaną, wsi rodzinnej Orkana Smreczyńskiego.

$\mathrm{Na}$ Skalnym Podhalu prawocenie się to pieniactwo. Prawocka to miejsce o które toczy się spór. Tak nazywają kawałek pola nad potokiem u wylotu doliny Małej Łąki, gdzie dłoga do Kościeliskiej doliny silnie się zakręca i obniża, o który niegdyś właściciel Zakopanego, Władysław Zamoyski, procesowal się z góralami.

W Źywieckiem nie mówią już prawocić się, ale prawow a ́́. „Prawował się Maciek lo (tj. o) łonke co mu jom Wilcosek zajom, bo sie wcinała poza ściyzke”. „A potym sie bijom, godzom i prawujom. I jest 10 (tj. dla) wsytikich kumedyja". ,Aleks a nder Zaremba: Stare pogadlki góralskie od Zywca. Zywiec, 1931. 16.). „Prawować się" w okolicach Myślenic i Bochni (Kazimierz Nitsch: Dwie gwary małopolskie - Krzyszkowice i Swidówka. Mater. i Prace Kom. Jęz. A. U. II. 377.), i dalej w stronach Iwonicza (,Lud". VI。46.).

W Zdzarach Eukowskich na Podlasiu (Barbara Mocarska w zapiskach Zakładu Dialektol. P.A.N.): ,Cego sie prawujes, nie prawuj sie tak". W tym samym znaczeniu w okolicach Białej na Podlasiu (,Rocznik Tow. Przyjaciół Nauk w Wilnie. I. 121.). W Podnieśnie Siedleckiem mówią: "P rawownik coby się stale prawował z ludziami, coby posądzal kogoś”. (Bogusław Kreja w zapiskach Zakt. Dial. P.A.N.). W Ostrowcach Buskich: „Wy nie wyprawujeta. - Prawujewa sie" (Feliks Pluta w zapiskach tamże). Nawet na Pomorzu Gdańskiem, jak Swernogadiach w powiecie chojni- 
cikm i w Stobnie u Borowiaków, tj. w okolicach Tucholi: „prawowac są", to procesować się. (Kazimierz Nitsch. Dialekty polskie Prus Zachadnich: Mater. i Prace Kom. Jęz. A. U. III. 172. i 277.).

Twierdzone prawo, iusiurandum, czyli przysięga

Aleksander Brückner przytoczył z naszej średniowiecznej łacińskiej poezji przykład (Rozpr. i Sprawozd. z Posiedzeń wydz. Filol. A. U. XXII. 41.), w którym do słów „Iure iurando”, dopisano: "W thwendzonem prawe", czyli że dany osobnik potwierdza swe zeznania przysięgą.

\section{Odpowiadać w prawie, czyli w sądzie jako świadek}

$\mathrm{Z}$ połowy XV. wleku $\mathrm{w}$ Kodeksie Suiętosławowym (Tłumaczenie polskie statutów ziemskich. wyd. Fr. Piekos iń ski: Archiwum Kom. Prawniczej. Collectanea ex Archivo Collegii Iuridici. wyd. Kom. Prawniczej A. U. III. 42. 5.): „Sprawą gych czągneny bily, a prawye polskem... powynny będze othpowyedzecz. Tamże (75): „Gysz (iż) lath... nyemayącz, odpowyedzecz w prawye na rzecz ne mogą".

Prawem odbyć, prawnie załatwić, iure evadere, czyli ognać się prawem, obronic się, wyjść z prawa

W rotach przysiag miasta Warki z 1426. roku (Franciszek Piekosiński.: Nieznane średniowieczne roty przysiag wareckie z lat 1419-1480: Archiwum Kom. Prawniczej A. U. T. VIII. 48.): „Iaco ya tho wyem, o ktore kkobily Dadzibog na Stanislawa zalowal (skarżyl) o thy on oczecz (ojciec) yego prawem odlbyl".

Wiadomość z 1447. roku z Mazowsza (Monumenta Iuris cura praepositorum Chartophylacio Maximo Varsoviensi edita, Pomniki Prawa. Varsoviae. 1912. III. 151.): „Iure ipsum evasit, vulgariter prawem sye ognala".

Eułasz Górnicki w ,Rozmowie Polaka $z$ Włochem 0 wolnościach y prawach Polskil" (bez roku i miejsca), pisal na str. F4. v.: „Y tych misternych sztulk, co ie zowią fortel, a zatracemiem dusznem pachną, prawo nasze przyczyną nia iest... tedy przysięże strona, iako o pozwie, y postepku przeciwko sobie nie wiedziała, y tak wynidzie, z dawnego prawa".

Nie posiadać miejsca zamieszkania w obrębie sądu, czyli w dawnym prawie

W ortylach magdeburskich (A l. Brü ckner: Magdeburger Urtheile. Ein Denikmal deutschen Rechtes in polnischer Sprache aus 
der Mitte dies XV. Jahrh.: Archiv für slavische Philologie. hg. Jagić. Berlin VI. 571.): "Czosz tu nye oszyadl w them prawye... czo thu $\mathrm{w}$ tem prawye nye bydly (mieszka po staropolsku, pozostało to $\mathrm{w}$ czeskim języku)": „Der yn dem gerichte keyn eygene wonunge hat”.

\section{Zakończenie rozprawy sądowej, czyli prawa}

Wiadomość z 1500 roku z ortyli (W. A. Maciejowski: Historia prawodawstw słowiańskich. wyd. II. T. VI. 1588. r.): „Konyecz thych praw stal szye w ponydzalek w szkolye (szkole) szkulszkyey", czyli w Skulsku, miasteczku po stronie południowo-zachodniej jeziora Gopła.

Prawem pokonany „iure victus”, ten któremu prawnie winę uodowodniono. „Convincere iure”, przemódz prawem, dowieść w prawie.

Chodzi tu o przywilej wydany przez Władysława Jagiełłe dla szlachty, streszczający się $w$ słowach: „Neminem captivari permittimus, nisi iure victum", tj.: „Nikogo nie pozwolimy uwięzić, jak tylko prawem pokonanego", czyli tego, któremu udowodni się winę. W przywileju jedlińsko-krakowskim $z$ lat 1430-1433, w którym ten to król nadal szlachcie na Czerwonej Rusi wszystkie przywileje, które posiadała szlachta $w$ głębi Polski, uczynił cztery wyjątki, mianowicie: gdy kogos pojmano na gorącym uczynku kradzieży, zabójstwa, podpalenia i gwaltu. Ogólna ustawa z 1588. roku, orzekała: „Na gorącym prawie (czyli na gorącym uczynku) starosta każdego pojmać zawsze może". Prawo to, wzbraniające uwięzienia bez sądu, wymierzone było przeciw możliwej samowoli władcy możności uwięzienia kogoś niesłusznie, jak to dzialo się zwlaszcza we Francji, gdzie jeszcze w przeddzień wielkiej rewolucji, Ludwik XVI. zwykł był wydawać swym zaufanym dostojnikom listy, na mocy których mogli oni, bez sądu i udowodnienia winy, kazać każdego uwięzić na czas nieograniczony. Wcześniej niż u nas, wydano odpowiednie prawo w Anglii, jako „Habeas corpus”, a na Węgrzech jako „Neminem captivabimus". Gdy jednak w tamtych krajach przywilej obejmował wszystkich wolnych obywateli, to $\mathrm{w}$ Polsce jedynie szlachtę, ktćra uważała siebie za właściwy ród. Król u nas zaprzysięgal ten przywilej przez ,pacta conventa".

W rękopisie Biblioteki Jagiellońskiej z okolo 1428. roku, Nr. 2503. (L u c jan Malinowski: Zabytki języka polskiego: Prace Filol. Warszawa. I. 486.) słowa: „Ego te convincam iure”, odiano przez „Ya czebe przemoge prawem".

Wiadomość z 1436 roku z zapisków sadu ziemskiego warszawskiego. (Zapiski i roty polskie XV-XVI. wieku z ksiąg sądowych ziemi 
warszawskiej. Whadysław Kuraszkiewicz i A a m Wo $1 \mathrm{f}$ : j.w. Nr. 482.): „O ctorego Mlinarza nyame (na mnie) wiganth (Wigand) szalowal (wniósł skarge), thegom snim nyesmowil po poswe (pozwie) gemy wrocisz i po dowedzeny w prawie".

Zapiska $\mathrm{z}$ Mazowsza $\mathrm{z}$ 1439, roku (Kazimierz Tymieniecki: Sądownictwo w sprawach kmiecych, a ustalenie się stanów na Mazowszu pod konliec wieków średnich. Poznańskie Tow. Przyj. Nauk. Prace Kom. Hist. T. III. zeszyt 137): „Mial szwym prawem dowiescz, a nye dowotl".

W "Kronice Swiata" Ma r cina Bielskiego, wedle krakowskiego wydania z 1564. roku, na str. 108, r.: „Patrycyusze nie dali, póki prawem nie będzie pokonan”; 119. r.: „Upominali się Trybuni od pospólstwa obiecanych praw uczynić exekucyą Patrycyom... Nie godzi się żadnego tracić, póki go prawem nie przekona kto"; 196. r.: „WydaI skazanie niesłuszne niezwyciężywszy mie pierwey prawem... $\mathrm{Pa}-$ pież Leo wezwawszy do siebie swey rady, uradzili między sobą wedlug swego prawa Papieskiego, to iest wedlug dekretów, Luterskie księgi popalić... Papież... ani mię pozwał, ani słuchał ani prawem przekonal".

Stan is 1 aw Orzechowski w slawnym dziele "Quincunx, tho lest wzor Korony Polskiey na Cyniku wystawiony", z 1564 roku, pisal o sobie, S3. r.: „Nie bylem nigdy pozwany, nie jestem żadnym prawem przekonany”; a tamże dalej: C4. r.: "Co ja w Polszcze z strony Wolności, iakso y $\mathrm{z}$ strony prawa... Przeto żadną miarą my Polacy pozwow od Krola, y iego użędnikow mieć niechcemy, a brania w więzienie prawem nieprzeikonanego... to iest grunt naszey Wolności, że nas Krol nie pożywa (pozywa), ani więzienia wźiąć może, aż przekona prawem. Wloch: Iako iest to dobry Statuit, iż się też pierwey mówiło, iż Król Szlachcica poimać nie może aż przekonanego prawem"; C.4 v.: „Y więc z tym czekać aż będzie taki przekonany prawem?"; Dl. r.: „A o prawie prożno myślić”; Hl. v.: „A naostatek boday nie latwiey zabić Szlachcica, niż go poimać podług waszego prawa... Instigatorowi bez delatora czynić prawa nie każecie... Ale wracając się do rzeczy oid ktorychżem odstąpił, to iest od prawa waszego, iako ie za sobą Iudzie niektórzy ciągną, y nimi sobie pomagają... Przysięgają, iż tego co mąż od nich sprawował u prawa, nigdy mu sprawować nie poruczały"; H2. r.: „A więc lepiej świadkiem dowodzić, iako w Cesarskiem prawie?"; H3. r.: „,Siła iest rżeczy w prawie wyszym, ktorych chwalić trưdno... nje imać nikogo, aż przekonanego prawem"; H3. v.: "Y insze nasze prawa... To y tu prawo złe prżyczyną iest tych wszystkich zbrodni... Wroćmy się do prawa waszego"; H4. v.: „A wysiedziawszy zostawiono mu całe prawo czynienia, o lekkość, by go było kiymi 
wybito na rybnych stolech... ten kto u was naprzod prawo knowal, trzeba mu bylo obaczyć pilnie ok oliczności wrszystkie... a wasze y bez jednania prawo porżuci, abo go odgrożą"; Kl.v.: „Otoż wy Polacy ostrego Prawa mieć nie chcecie, ktore ma być iako Tyran czlowieksowi, urżędu surowego nie cierpicie, ażeby exequutia była prawu tego Boże uchoway. Więc Prawa bać się niechceoie, a bannitow czci odsądzonych, zuchwalczow poniewoli bać się musicie”; K2.r.: „Ale iusz - tym prawie waszym niechay koniec będzie, bo trudno wyliczyć dako wiele złego $z$ tego waszego prawa roście, a nie zbrodzień w Polszcze złego, aż pierwey upatrży $w$ prawie dziurę, kitorą $z$ oney zbrodnie wyniść ma, abo się prokuratora poradzi"; S2.v.: „Prawo zakazuje kraść, tym takowym Prawem niepierwey zlodziey zginie, aż świadiki, albo licem (tj, osobisisie) przekonany we złodzieystwie będzie".

Tenze Stanislaw Orzechowski w „Rozmowie okolo Exequucyey”, wyraził się na str. H4. v.: „Bislkupowi... należy definire, liz to iest Heresis, a potym onego Prawem przepartego, iesliżeby sye kaiać nie chcial, zakląć, a gdzieby y na klątwe nieidibał, Krolowi oznaymić, aby Krol ono kacerstwo z urzędu swego Krolewskiego karal, wedle prawa swego Krolewskiego".

Eukasz Górnicki w „Rozmowie Polaka z Wlochem” na str. A4. r.: „Ani mnie do więzienia wziąć może, aż przekonanego prawem”; B1.r.: „A u nas nikogo do więzienia brać się nie godzi, aż przekonanego prawem. Włoch: Tak jest iź ów co zbroil, ma się z czego cieszyć, że się pod takiem urodzil prawem, ale ów zasię, kogo ukrzywdzono, bardzo lamętuie na takie prawo, y oyczyznę w ktorej się urodził, dla takiego przeklina prawa... Ukrzywdzeni na prawo Polskie lamentną. Dobry a cnotliwy człowiek, ma naysroszse przyzwolic prawo, bo ufa swey cnocie, a więzienia się żadnego mie boi, chociażby y tam żył, gdzie nie przekronane prawem do więzienia biora"; B3 v.: „Pozostawy go, on woźnego sthukszy, do prawa nie stanąwszy, odpowie ieszcze onemu, co go pozwał... a to wszystko ucżyni... wiedząc że go poimać nie mogą, aż przekonanego prawem"; B4. r.: „Wenetom u których jest prawdziwa Wolność, wolno by taki Statut postanowić sobie, iżby ich nie imał nikt, aż przekonane prawem... a wżdy wielokroć nie przekonane prawem, nie tylko imano, y dawano do więzienia, ale y przed oczyma wszystklich zabijano"; B4. v.: „Wskaże do strony o iednanie, na ktore gidy on ukrzywdzon nie będzie chciał przyzwolić, ale będzie podbierał prawem, asz $\mathrm{ku}$ wywolaniu... powie żem takk uczynić musial, bo mię chciał zgubić prawem, a iednać nie chcial... przeto imać się takiego nie godzil aż przeikonanego prawem"; C1. v.: "Co się stać może, a nie stało się, tęo nie sądzí prawo... prawo iakom pierwey powiedział od tego, żeby karało zle ludzie"; C2.v.: 
„Bo się rychlo prawo skończyc̉ nie może... a co wyjezdzasz na plac $\mathrm{z}$ tem twoiem Polskim prawem. Prawo to wasze tylko uczynek zły gdy się stanie, kaźń maluczką iakąś... ale żeby złości grzechy, okrucieństwa bydź nie mogły, temu $z$ żadney strony wasze prawo nie zbieżalo... Talkie też lepsze to prawo, ktore zabiega temu, żeby czlowiek źle nie czynil, niźli to ktore złości iusz popełnione karże. Lepsze to prawo ktore zabiega żeby y zle uczynki nie były. Polak: Ostre jakieś ustawy, kitore barziey do obyczaiów niż do prawa należą"; C2. v.: „Włoch: Gdzie ma bydź dobrże postanowiona Rzeczpospolita tam trzeba $\mathrm{y}$ prawa dobrego, $\mathrm{y}$ dobrych obyczaiow... Krolestwo, w ktorem ieśli prawa są nie doskonałe, ale wżdy obyczaie dobre się nayduią. Ale tu u was, y obyczaie nader złe z waszey sweywoley, y prawa nie barżo są chwały godne... Więc rada Koronna nie dopuśal tego Krolowi, żeby nad prawo, nad swą przysięgę mial co czynić"; C3.r.: „To ia powiadam co dawno, prawo samo pokoy nie czyni... iakoż tu prawo pokoy czynic"; C3. v.: "Włoch: Wszystkie są tu od electiey począwszy, o Wolnosci waszej mowi, a o prawie, y o czym inem może ieszcze bydż rozmowa”; D3.r.: „A wżdy tym ktorży po Wlosku chodzą, rząd się nasz y prawo nie podoba... nas nie teskno, alebyśmy nigdy na wysze Wolności, y na wasze prawa niefrymarczyli... Chwalicie swoie laskawe prawo... Prawo laskawe na dawne dobre ludzie iest postanowione... też występki pierwey nastały niźli prawa... Ale na te dziwne teraźnieysze niesłychane zlości, lusz inakszego potrzeba prawa... Więc prawa laskawe macie, a ludzie po tem prawem żyiąc, olkrucieństwa nad swą bracią niesłychanego używają. Czy to dla tego macie laskawe prawo, iżbyście wy sami okrutnikami byli? Zleć wszędy okrucieństwo, ale na okrutne ludzi okrutnego potrzeba prawa... Rzymianie do Grecyey słali dla przyniesienia prawa, żeby ztamtąd do Rzymu prżynieśli prawo"; D3. v.: „Y Wenecya nie z tym ci rozumem, nie z tym prawem ktore ma teras, ani z tą Wolnością zasiadła, ale za czasem od mędrszych niż sami dostali rozumu”; D4.v.: „A naostatek y pisane, y nie pisane prawa, wszystko to poydzie z dymem. Aleć wasze prawa nie widzę dla czego by ich, gdy na nie śmierć przyidzie żałować trzeba, bo są piesczone barżo, a ostrych praw, abo tych ktoreby zabiegały temu, żeby złoczyństwa nie było, wy żadna miarą nie chcecie: ale wy takie prawa mieć chcecie, ktoreby mamniey nie urażały... Ale w prawie naszem, niewiem co widzisz talkiego, pszeczby się abo tobie, abo komu na świecie pođobać nie mialo. Czy lepsze wasze Cesarskie, z ktorego się y wasisz Doktorowie wypleść nie mogą? $\mathrm{Ba}$ proszę cię powiedz, w czym winuiesz nasze prawo?... Nie wiem iżbyś co przeciwko prawu naszemu mogł mówić słusznego... Sami to prżyznawacie bo od dawnych lat, na każdym 
Seymie o Corecturze prawa swego mowicie"; E1.r.: "Iako są spisane prawa Cesarskie za Iustyniana Cesarza, przez trzech mężów do tego wysadzonych. Polak: Wierz mi że prawa nasze są dobre, y nie możesz ich szkalować... Mow o prawie iakoś mi obiecał wczora”; H3. r.: „,Siła iest rzeczy w prawie waszym, kxtórych chwalić trudno... nie imać ni"kogo aż przekkonanego prawem".

Wyrażenia ,prawem pokonany" używano też ni z za léznie od przy wile ju.

W księgach ziemskich $w$ 1498. roku zapisano (W. A. Ma cie jowski: Historia prawodawstw słowiańskich. Warszawa, 1858. T. VI. 275.): „Jeśliby ktho plinącz s trafftha... jaz wylomyl... thakowi ieśliby byl.: pokonan wedlye... prawa wodnego... ma zaplaczicz": „Quando aliquis fluens cum struibus... obstaculum effregerit... talis...-a parte iure aquatico convictus... debet condemnari".

Gorące prawo, gorący sąd, byly to sprawy sądzone natychmiast za przestępstwa, schwytanych na ,gorącym uczynku".

W ortylach, czyli wyrokach sądów miejskich z XV. wielku (W. A. Mf a cie jow ski: Historya Prawodawstw Słowiańskich. j.w. 62. CIII.): „Ghestlhy powynyen przysząsznyk... przydz ku sządu na poloszony (oznaczony) dzyen, albo ku gynnemu (innemu) gorączemu szadowi (sąđowi), gidy mu przykażą”. Tamże (str. 130. CCXXXX.): „Gdy szye stanye... czo thakyego acz by myano gorączy szad gaycz".

W podobnym źródle $z$ tegoż czasu (A l. Br ückner: Die Magdeburger Urtheile: Arch. Slav. Philol. wyd. Jagić. Berlin. 1884. VI. 387.): „Gdy szye stanye beszprawna rzecz przed polnoczą.. aczby myano gorączy sand sandzycz albo gaycz"; (VII. 553.): „Stanyelysze ktora (jeżeli się stanie która) nyevrzadna (nierządna, przestępcza) rzecz, o ktiorą by czynycz gorącze prawo".

Znow z tegoż czasu (Stefan Vrte1-W ierczyński: Wybór tekstów staropolskich. Czasy najdawniejsze do 1543. roku. Lwowska Biblioteka Slawistyczna: T. XII. 117.): „Prawo o glowa (głowę), albo o rany, czo nye stasthano (zastano) za goraczą (gorącą), tho ma dacz do zagayonego szandu".

Wedle ustawy z 1520 . roku: ,Goracemu prawu o gwalt miejski od szlachcica dawnośc nie szkodzi", czyli nie istnieje przedawnienie; znów z 1523. roku: „W gorącym prawie Urząd zawsze gotowy być ma", tj. urząd obowiązany jest działać zawsze w sprawach przestępców schwytanych na gorącym uczynku.

Wedle uchwały z r, 1543. było to równoznaczne z "recens crimen", przed uplywem jednego roku i sześciu tygodni. Ograniczeniem ,ne- 
minem captivari permittimus", byla ustawa z 1588. roku, orzekająca, - że „Na gorącym prawie starosta każdego pojmać zawsze może”, jak to wspomnieliśmy wyżej.

Marcin Bielski podał w swej "Kronice Swiata” na str. 418. r.: „Poiman Slabosz i przywiedzon na Ratusz, osadzili o nim prawo gorące, y ścieli". 418. v.: „A od tego czasu uchwalono dest ten Statut, aby urząd miejski nie tracil żadnego szlachcica gorącym prawem (na marginesie:) Ustawa o ścięcie Slachcica - przy ktorymby nie było urzędu Grockiego, tho iest Starosty albo Podstarościego: iesliby inaczey czynili, Burmistrz ze dwiema Raycy ma gardło dać".

Eukasz Górnicki w swym dziele: „Rozmowa Polaka z Włothem o Wolnościach y prawach Polski (bez roku i miejsca wydania) na str. E3. v.: „Aleby y około gorącego prawa inaczey postanowic trzeba. Y Magdeburskie prawo, ktore się też Czartu godzi, niech przy mich zostanie, ale ia mowię o Szlachcie y dziwię się, czemuście na się tak głupie postanowili prawo".

Przytaczamy zapiskę $z$ akt squdu $w$ żywcu $z$ 1608. roku, które to miasto niegdyś $w$ księstwie zatorskiem leżące, posiadało władzę w sprawach karnych nad całym sąsiednim okręgiem górskim. (S tanislaw Szczotka: Akta spraw złoczyńców miasta Żywca: Archiwum Etnograficzne. Prace wydaw. przez Pol. Tow. Ludoznaw. jako ręlkopisy. Nr. 3. str. 39.): „Podany będąc na gorące prawo Piotr Radwan z Cięciny wyznal, iż chodził po salaszach", czyli że szałasy pasterskie okradał.

Być przed prawem, stać, ustać $w$ prawie, prawu stać, iure pracedere, rozeprzeć się prawem, w prawo wstawić, przyjść ku prawu, czyli stanąc przed sądem.

Zapiska z 1461. rolku z ksiąg sądowych ziemi warszawskiej (Zapiski i roty polskie $z$ XV-XVI. wielku z ksiąg sądowych ziemi warszawskiej: wyd. Wladysław Kuraszkiewiez i Adam Wolff. 1950. roku. Prace Kom. Jęz. P.A.U. Nr. 1146.): „Podlug smowy bylem v szochaczewye ( $w$ Sochaczewie) przed prawem" Tamże z 1452. roku (Nr. 930.): „Jakom ja nyewzdal (nie ustal) w prawye o stha (sto) grzywien prze(ciw) Janowi Cprissowi (Cyprysowi) Crakowskiemu (Krakowskiemu) contra Parissowi”". Tamże z 1472. roku. (Nr. 2. 963.): „Kthora czascz napyrwe roky zyemak przeth prawem myal vssdacz, (stanąć), y w kxagy (księgi) wyecznącz zapyssacz (wieczyste zapisać)".

Wyrażenie „prawu stac" użyte jest w Kodeksie Swiętosławowym z drugiej połowy XV. wieku (Tłumaczenie polskie Statutów Ziemskich wyd. Franciszek Piekosiński: Archiwum Kom. Prawniczej A.U. Collectanea ex Archivo Collegii Juridici. III. 221-334.). 
Z aktów sądowych w Pyzdrach nad Wartą, w połowie drogi między Poznaniem a Kaliszem, z lat 1410-1418. (W ładys 1 a w Kuras zkiewicz: Najdawniejszy przejaw zbieżności ghosek rz i ż u pisarza pyzdrskiego $z$ lat 1410-1418.: Język Polski. XXXIII. 389.): „A temu szą trzy lata minela nysz Katazyna Sandziwoya w prawo wstavila".

Wiadomość $z$ XV wieku (Stefan Vrtel-wierczyński: Wybór tekstów staropolskich. Czasy najidawniejsze do 1543. roku. Lwowska Biblioteka Slawistyczna. XII. 1930. r. 119.): „Gdyby geden czlowyok, zatwierdzon $w$ naszem prawie, rok $y$ dzyen o glowe, albo o rany... a $\mathrm{w}$ them czaszye nye przyszedl ku prawye"...

Iure procedere, rozeprzeć się, czyli wystąpić $z$ prawem $w$ sądzie

Zapiska z sądu w Przeworsku z 1498. roku (Akta Grodzkie i Ziemskie $z$ czasów Rzpltej Polskiej w Archiwum Bernardynów we Lwowie. 1868. T. XIX, 116.): „Donec Dorothea cum fratre... iure procedent, alias rozszeprą szye prawem".

Oglądać i zeznawać przed prawem, czyli w sądzie

Wiadomość $z$ artyli z polowy XV wieku. (A l. Brückner: Magdeburger Urtheile. Ein Denkmal deutschen Rechtes in polnisczer Sprache aus der Mitte des XV. Jahrh.: Archiv für slavische Philologie kg. Jagić. Berlin. VI. 345.): „Sządza gye ogladacz (oglądacz) ma thy rany, y przed prawem gye szesznawacz (zeznawać)".

Ad decisionem iuris, do rosparcia, czyli rozstrzygnięcia sprawy.

Zapiska z 1474. rolku z sądu w Przeworsku (Akta Grodzkie i Ziemskie z czasów Rzpltej Polskiej w Anchiwum Bernardyńskiem we. Lwowie. T. XIX. 20.): „Ad decissionem iuris, do rosparczya prawa".

„Do przesla prawa, ad finem litis", czyli do 'końca sporu

Tak zapisano $w$ 1490. roku w aktach sąów grodzkich Iwowskich (Akta Grodzkie i Ziemskie j.w. XVII. 263.).

Prawem odbyć, czyli gdy spór już został załatwiony, odbył się

W zapiskach sądowych ziemskich warszawskich (Zapiski i roty polskie XV i XVI. wieku z kssiagg sądowych ziemi warszawskiej. wyd. 
W ladyslaw Kurasiewicz i Adam Wolff. 1950. r. P.A.U. Prace Kom. Jęz. Nr. 371.) z roku 1432: "O ctore penądze Jachna namą zalowala (na mnie skarżyła), thichem prawem odbyl". Tamże z 1448. roku. (Nr. 819.): "Oczsom (oczom) ya Jana odbyl, otom snym nemyal wtore gednaczow szadzić (pojednawców ustanawiać)".

Prawem przeprzeć, czyli dopiąć

W zapiskach sądiu ziemskiego warszawskiego z 1437. roku. (Zapiski i roty polskie XV-XVI wieku z ksiagg sądowych ziemi warszawskiej. wyd. Władysław Kuraszkiewicz i A am Wolff. r. 1950. P.A.U. Prace Kom. Jęz. Nr. 495.): „O ctore gymene (imienie, czyli majątek) Zophia (Zofia) na me zalowała (skarżyła), thom ya pirwey cupil (kupil) nisli ona prawem przeprzała".

Prawem obchodzić się, dokonać sądowych oględzin

Zapiska sądowa ziemi warszawskiej z 1461. roku. (Zapiski 1 roty polskie XV. i XVI. wieku z ksiąg sądowych ziemi warszawskiej. j.w. r. 1950. Nr. 1097.): „Ssza mnye then yas (jaz) dostal, gdym sza dzelyl z Yanem ho kthori ssza prawem hobichodża".

$$
\mathrm{Z} \text { prawa - extra forum, poza sądem }
$$

W kodeksie Swiętosławowym (Trumaczenie polskie statutów ziemskich. Kodeks świętosławów. wyd. Franclszek Piekosiński: Archiwum Kom. Prawniczej. Collectanea ex Archivo collegii Iuridici. wyd. Kom. Prawniczej A.U. III. 42.5.): „Spraw.a gych czągneny bily, a $w$ prawye polskem... powymny beidze othpowyedzecz".

Wiadomość z XV wieku (Stefan Vitel-Wierczynski: Wybór tekstów staropolskich. Czasy najdawniejsze do 1543. roku. Lwowska Biblioteka Slawistyczna. T. XII. r. 1930. 117.): „Ale ya nye wyem, maly tha mocz a prawa dasz gey tho wyano... gdysz gey nye wyanowano przed prawem".

Zawite prawo, ius peremptorium, czyli ostateczny wyrok

Wiadomośc z 1450. rolku z Mazowsza (Monumanta Iuris cura praepositorum Chartophylacio Maximo Varsoviensi edita: Pomniki prawa. Varsoviae. 1912. III. 189.): „Fideiusserunt... ad statuendum in pereinptorium ius, vulgariter na zawithe prawo". 
Ius complere, prawo czynić, zadać, czyli wyrok wykonać

W zapisce wielkopolskiego sądu grodzkiego z 1391 roku. (J ó zef Lekszycki: Die ältesten grosspolnischen Grodbücher, Poznań. I. Nr. 981.): „Jakub wiszedi, Jakuszowi ne uczinifszi nigednego prawa”. W ortylach z XV. wieku (W. A. Maciejowski: Historya prawodawstw slowiańskich. Warszawa. XXXVII. 1856. r. 38.): „Mogly nad yego prawo udzyelacz yako nad szlodzyegyem (zlodziejem), poka ony byly $w$ radzye". (Tamże XLIX. 44.): „Mozeczye dobrze w lawyczy (w lawie ławniczej) na szadzye (sądzie) szyedzyecz ,y prawo wyrzec, albo wydawacz".

W zapiskach sądowych województwa sandomierskiego z XV, wiekku (Franciszek Piekosiński: Zapiski sądowe województwa sandomierskiego: Archiwum Kom. Prawniczej A.U. VIII. Nr. 668.): „Petrus... obowiązal sę czynicz praw swimi ludzmi na dzen zawit1 (oznaczony), a ne uczinil".

W zapiskach $\mathrm{i}$ 'rotach polskich $\mathrm{z}$ XV-XVI. wieku, z ksiąg sądowych ziemi warszawskiej (wyd. Władysław Kuraszkiewicz i Adam Wolff: Prace Kom. Jęz. P.A.U. r. 1950. Nr. 391.) z roku 1432: „Jakom ya do Hyncze (Hinczy) slal (stał) by mi prawo zapotra (za Piotra) uczynil, albo potra (Piotra) dal, haon (a on) thego neuczinil". Tamże z 1472. roku (j.w. Nr. 3.067.): "Iaco cztindzesoi groschi gwaltem Schimonowy kmeczowi oth nych prawa nyezadajancz (nie zadając)". Tamże w tymże roku (Nr. 3.059.): "Iacom ya a samodzeschath czlowyeka Woczecha (Wojciecha)... ndrodze dobrowolney nyeszbil gwalthem, anym go gymal (imał), any wyazal (wiązal), prawa neyzadawschi".

\section{Prawo podało, czyli oddało w czyjeś ręce}

W zapisce sądowej z Wielkopolski z 1401. roku (F ranciszek Piekosiński: Wybór zapisek sądowych grodzkich i ziemskich wielkopolskich z XV wieku. Kraków. 1902. r. 55.): „Czso gąl (co jąl, ują) czloweka Woyczecha Mancewo, to mi gi prawo podalo y w pączesm gi trzimal (w pięciu go trzymalem), ys mi gi prawo podalo".

Prawo w znaczenfu wyroku, albo tortur w sledztwie i kary (censura)

$\mathrm{z}$ zapisków sądowych lwowskich z 1403. roku. (Akta Grodzkie i Ziemskie z czasów Rzpltej Polskiej z Archiwum Bernardyńskiego we Lwowie. XVII. 126.): „Micosz wząl na Petrku sprawne XXX marcas, ysze mu ye prawo skazalo". 
W kazaniu husyty polskiego $z$ okoto 1450. roku. (A 1. B r ü ckner: $Z$ rękopisów petersburskich: Prace Filol. Warszawa. IV. 576.): „Per censuram", objaśniono slowem: „prawem”.

W „Kronice Swiata" Marcina Bielskiego, w wydaniu krakowskiem z 1564. roku. 115. r.: „Krol Leydam (czyli Jan z Leydy, król anabaptystów) kaiał sie... Ale ini dwa, zwłaszcza Kniperdoling niechcieli ich (Krześcijanów) słuchać nauki, uczyniono tedy ich prawo, targano je kleszczami rospalonymi, mieczami pothym przebiwszy, uczyniono na tho klatkę żelazną, w którą dwu s nich włożono"; 229. v.: „Potym Cesarz z woyskiem przyciagnąl pod Witemberg, dinia 4 Maia, trzeciego dnia osadził prawo o Kurfierście, tam skazan na śmierć przez miecz”; 321.v.: „Horimirz zamiotal ony gory (tj. kopalnie), iż ich potym trudno miał ktho dobyć, y gornilki pobił. Książe kazał go poimać y wsadzić, prawo o nim udziałano, sciąć, a spalić"; 367. r.: „Konrad namówił służebnika Lutka, aby pana swego do mnie żywo przyniósł albo głowę iego, slubuiąc go panem udziałać. A then Lutkowi dal był oyca ściąć a prawem osądzonego Henryk iż byl zabil thowarzysza drugiego"; 370. v.: „Na wysłuchanie sprawy o Pomorską ziemię, y koniec według prawa, a sprawiedliwości uczynienie".

Eukasz Gornicki w dziele, „Rozmowa Polaka z Włochem o wolnosiciach y prawach Polski" (wydanem bez oznaczenia miejsca i roku) na str. A4.r.: „Przecię ja nie wiele pomnię, ktoreby za to skarało prawo"; A1.v.: "Prawem się to opatrzyć może, iżby ten sklarany był”; A4.v.: „Jeśli na zbrodnie skarga nie była, a prawo y urzędnicy niewinni, że nie karali... ieśli niechce podlegać prawu, ieśli sądu nad soba nie cierpi... gdyby tu prawdziwa Wolność byla, kztora bez rządu y dobrego prawa bydź może... Polak... a ono swawola tam bydź nie może gdzie iest prawo"; B4. v.: "Aieśli cię to obraża iż o małą rzecz u nas wezmą, potrzebne iest talkie prawo... Y Dootora tego ktoryby miasto lekarstiwa dal choremu truciznę srożeyby prawo skarać miało, niż gdyby doby'wszy broniey iawnie człowieka zabił".

Sąd miejski w ży cu posiadał władzę karną nad okręgiem żywieckim, skąd wiadomość z 1589. roku, że przestępca: „Za wtórnym powstaniem podan był na mękę, w ktorych mękach prawa wytrzymå, a znać (przyznać) się do niego nie chcial". (S ta n is $¥$ a w Szczotka: Akta spraw złoczyńców miasta. Żywca: Archiwum Etnograficzne. Prace wyd. przez Pol. Tow. Ludoznaw. jako rękopisy; Nr. 3. str. 16). Osobon omawialiśmy ,gorące prawo".

W Prandocinie w miechowskim powiecie, „chodzili po prawo", czyli dla usłyszenia wyroku (,Wisła”. XVI. 60.).

W. Czarnym Dunajeu urządzono wesolą zabawe zbiorową zwaną bursa. (Andrzej Stopka: Materialy do etnografii Podhala: 
Mater. Antrop. Archeol. i Etnogr. A.U. III. 149.). Kiedy komuś wymierzono przewidzianą zwyczajem żartobliwą karę, ogloszano: „Wiwat! skóńczone prawo!".

\section{Przewód prawa}

Eukasz Górnicki w Rozmowie Polaka $z$ Wlochem o wolnościach y prawach Polski”. pisał na str. H.1.r.: „Idz ani w pozwie, ani o przewodzie prawa niewiedziały, y prżysięże krzywo... Dopiero po prźysiędze prawo sie iego pocznie... Tu dopiero on dobry czlowiek stanął, y powiedział, iż ani o pozwie, an io przewodzie prawa niewiedzial”; L1.r.: „A nie miał pozwany wymowki żem niewiedział o pozwie y prżewodzie prawa... procuratorowie żeby nie mieli mieysca u. prawa stania".

\section{Pytać ,prawo, zapytywać sąd, wyznać przed prawem}

Wedle ortyli z polowy XV. wieku (A 1. B r ückner: Magdeburger Urtheile, Ein Denkmal deutschen Rechtes in polnischer Sprache aus der Mitte des XV. Jahrh.: Archiv für slavische Philologie hg: Jagić. Berlin. VI. 389.): „Pytam prawa gdysz Barbara $\mathrm{W}$ kupyenym tego domu wspomya nyą tako ysz pogego (po jego) szmyerczy myecz (mieć) ten dom".

Wiadomość z 1469. roku z kssiąg ziemskich warszawskich (Zapiski i roty polskie XV-XVI. wieku z ksiąg sądowych ziemi warszawskiej, wyd. Władyslaw Kuraszkiewicz i Adam Wolff. P.A.U: 1950. Prace Kom. Jęz. Nr. 2. 979.): „Jakom ya kmecza Jana do pythanya prawa... wząl".

Zapiska sądowa $\mathrm{z}$ XV. wieku (W ackaw Aleksander、 Maciejows ki: Historya prawodawstw słowiańskich. Warszawa. 1858. T. VI. 71.): „Panye woycze, ysz bo czya (cię) pytham na prawye”. Tamże (96): „Wysznali (wyznali) ktho ten uczynek przed prawem, tego mayą takyesz osządzycz (osądzić)".

De iure lucrari, iure vincere, czyli odbić, dobyć, zwyciężyć prawem

$\mathrm{Z}$ rot przysiag krakowskich $\mathrm{z}$ 1406. roku (R o muald Hube: Roty przysiąg krakowskich z konca XIV. wieku. Warszawa. 1875. 83.): "Wanek prawim prawem odbil Szwanthoslawa o mlin".

Wiadomość z XV. wieku z artyli, czyli wyrolków sądowych miejskich (Stanisław Estreicher: Nieznane teksty ortyli mag- 
deburskich: Studia staropolskie: Księga ku czci Al. Brücknera. Kraków. 1928. 101.): „Prawem dobycz - de iure lucrari”. (W. A. M a ci ejewski: Historia prawodawstw słowiańskich. wyd. 2. T. VI. Warszawa. 1858. 84.): „Dobywać prawem - iure vincere”.

$\mathrm{Z}$ około 1500 roku. (E $\mathrm{mil} \mathrm{Kałuż}$ icki: Kleinere altpolnische Texte aus Handschriften des XV, und des Anfangs des XVI Jahrhundertes: Sitzungsberichte der philos.-hist. Classe d.K. Akad. der Wissenschaften. C1. Wien. 1882. 180.): „Czo by doma nye byl a kako dlugo (jak dlugo) doma szą prawowal, az by go prawem dobyl".

$W$ księdze ziemi czerskiej $z$ lat 1404-1425. (Liber terrae Cernensis. wyd. T. Lubomirski. Warszawa. 1879. XXXVII.): ,Zadnym goprawyem nie zwyczaszy (zwycięży), o dktore swym prawem dosyadzą"

Prawo idzie, czyli obowiązuje, wymaga wykonania, stanowi

Marcin Bielski w „Kronice Swiata": 348.v.: „Stanisława Biskupa $k$ temu przyzwawszy. Biskupa pytano, ktory prawem dzierźy tho imienie... kupna nie wpisano $w$ ksieggi ziemskie, gdyż iuż na ten czas pisać umieli i prawa szły, zwlaszcza o thak wielka rzecz, ktora szła o grunt dobry dobrey wsi nie szukaiąc światków".

Stanislaw Orzechowski w ,Rozmowie albo Dyalogu około Exequucyey Polskiej Korony”, z 1563. roku, pisal: „T1.r.: „Piąta Seymowa questia iest, jakoby nam Prawa szły, a sprawiedliwość rychła".

Łułasz Górnicki w ,Rozmowie Polaka z Wlochem o wolnościach y prawach Polski (wyd. bez roku i miejsca), na str. E2. v.: „Prawo iest ktore pismem stanowi co chce, abo roskazuiąc, abo zakazuiąc... Prawo prawi iest, wynalazek, y dar Boży. Nie każeć prżecie prawo zabijać. J1. r.: „Postanowili byli takie prawo, iż podidanemu wolno było odyść od Pana... Teraz co nowe Mazowszanie, w wżekomo mędrszemi nastawszy zepsowali to prawo"; L2.r.: "Temu, kto prawa-stanowić, a dobre obyczaie ludzi zaprawić ma... Polak: Iżeś obyczaie wspomniał, radbych słyszal, co ieszcze o nich powiesz, gdyż gdzie te są dobre, tam y prawa źle iść nie mogą... żeby między wszystkiemi na świecie Iudźmi gorąca milość była, nie byłoby potrżeb prawa".

\section{Dane prawo - data lex}

To wyrażenie zawarte $w$ glosach polskich $w$ rękopisie z kazaniami lacińskiemi z połowy XV. wieku (R a 1 a l L ubicz: Sprawozd. Kom. Jęz. A.U, V 270。). 
Prawo stawić, ustawić, ustanowić, postanowić, dać, nadać, uczynić, prawem opatrzyć

W Kodeksie Swiętoslawowym z około 1450. roku (thomaczenie polskie Statutów Ziemskich. wyd. Franciszek Piekos iński: Archiwum Kom. Prawniczej A.U. Collectanea ex Archivo Collegii Iuridici 6.): „Na wyekugystą (wiekuistą) i rzeczi pamyącz ustawyenya ,a prawa smi uczynili".

W Kronice Swiata Marcina Bielskiego, wydanej w Krakowie, w 1564. roku, na str. 7.v. zapisano: „Bolus potomek Nemrotow panowal $\mathrm{w}$ Babiloniey siedmidzyesiąt y pięc lat, po iego śmierci syn Ninus napirwsze bałwochwalstwo wymyślił przez obrazy, gdy kazal obraz ne iego grobie do słupa zawieśić, y prawo dal mocne, kto sie do niego uciecze, by nagorszą rzecz uczynił, mial być wolen"; 8. v.: „Czasu krola Salomona krolował Smerdes, drudzy po nim aż do Amazym drugiego, ktory Rzeczpospolitą y prawa Egipczanom ustawił, tak iz y Solon Grek y Whosy wiele iego praw naśladowali”; 24. v.: „Po Melliseusie Jowisz był, ten ieszcze tych modlarstw więcey rozsiewał, chodząc po świecie, brał znajomość z ludźmi wielkimi a nowe rzeczy im pożyteczne y prawa ustaniawial, ktorych rzeczy ieszcze nie znali na ten czas”; 75. v.: „Dydo... w mieście Kartago... prawa obywatelom wszem onego kraiu rządnie wynalazła... w uczciwe prawa ustawiła"; 102. v.: „Praw y onych rzeczy używać ustawił”; 233.r.: „Aby sąd porządny prawa ustawił, a sędzya kniemu godne przydał"; 310 . r.: „Albowiem sie dzisiejszy od nich wyrodzili, a tho za ieden dziw iż praw nie maiąc... Pothym gidy sie iuż poczęli obaczać od postronnych Iudzi, ustawili między sobą prawa”; 319.r.: „Libiusza po wykonaniu wesela a elekciey, prosila go obec o posthanowienie praw, ktoremi by sie wszytka ziemia sprawowala”; 356.r.: „Widząc Kazimierz tę chuć k sobie odrzucil brackie (wydane przez brata) ustawy, łupiestwa, y okrucieństwa, a prawa słuszne y sprawiedliwe wszystkim ułożył"; 360.r.: "Ten to Henrik (Brodaty) wiele praw dobrych ustawil a zle wygladził"; 363. r.: „Thegoż roku Bolesław (Wstydliwy) Monarcha Polski chcąc ozdobić Krakow dobrym rządem a chędogośclą, dał mieszczanom Krakowskim prawo Niemieckie, y woyta im ustawił"; 374.v.: „Uczynil Krol Kazimierz syem (sejm) w Wiślicy, na ktorym ustawił prawa pospilite. A... prawo Niemieckie na zamku Krakowskim postanowit"; 376. v.: „Polskie krolestwo gospodarstwem, czuynością, thakież prawy ustawy, budowania, y innymi rzeczami dobrze opatrzył".

Stanisław Orzechowski w ,Rozmowie albo Dyalogu około Exequucyey Polskiey Korony" z 1563. roku: E2. v.: ,Boiaźń Bożą maiąc, sobie Prawa ustawiali... Otoż masz trzy Onoty, na ktorych Ko- 
rona Polska, Prawem i Statutem swym wsiadla: Prawda, Wiara, Sprawiedliwość".

Eukasz Górnicki w „Rozmowie Polaka z Włochem o wolnościach i prawach Polski”, pisał: E3.r.: „Otosz temu folgowali przodkowie naszy, iż uczynili takie prawo... nie namowi ich prżecie żaden na taikie prawo, żeby się talk iako konie płacić mieli".

Prawo przykazało, wedle, podług prawa czynić, postępować prawem prawo wiąże, znajduje, mówi i jako prawo jest, itd.

Wiadomość z 1393. roku z sądu ziemskiego krakowsikiego (B oleslaw Ulanowski: Starodawne Prawa Polskiego Pomniki: Antiquissimi Libri Iudiciales terrae Cracoviensis. A.U. VIII. No. 8, 668.): "Czom zamierzil, zamierzilem s prawem".

Wiadomość z 1402. roku, w zapiskach sądowych grodzkich i ziemskich wielkopolskich Franciszek Piekosiński: Studia, Rozprawy i Materiały z Dziedziny Historii Polskiej i Prawa Polskiego. Kraków. 1902. VI. 108.): „Jacom (jakom) ne wzonl Janowy iego bidla... ledno tczo (to co) my prawo przikasalo". (Tamże 362.): „Czso wyeprz Janowi zabith, to gi zabito z prawem".

Zapiska $z$ 1417. roku. (Adolf Mysłowski et Waclaw Graniczny: Matricularum Regni Poloniae Codices s. XV. conscripti: Monum. Iuris. Pomniki Prawa. Varsoviae. 1912. II. 297.): „Jacos ostal winne podlug czasu y prawa gy (i) wisedl ne doszedząc casu".

Wiadomość z 1419. roku $z$ Warki (Franciszek Piekosiński: Nieznane sredniowieczne roty przysiąg wareckie: Archiwum Komisji Prawniczej A.U. r. 1907. VIII. 44.): „Jacom ya Climkowi czinil prawo podluk smowi (smowy, czyli umowy)".

Zapiska $z$ Wielkopolski $z$ 1430, roku. Józef Przyborowski: Vetustissiman adiectivorum linguae Polonae declinationem, monumentis ineditis illustravit. Poznań. 1861. 22.): „Kedisz mala (miaha) Jagnesksa s Dambrowky soltissem prawem czynącz, tedis (tedyż) tam przed gaionim veczem (gaionym wiecem) nye szalowala (żałowała, tj. wnosiła skargę) o polosmy grziwny".

Wiadomość z 1453. rokku z Mazowsza (Ka zimierz Tymien i ecki: Wolność kmieca na Mazowszu w wieku XV. Poznań. 1921. Pozn. Tow. Przyj. Nauk. Prace Kom. Hist. XV. 55.): „Secunda zaloba (druga skarga): esze (iż) mi bronisz mich ludzy, czsszo (co) mę na ne prawo wyązalo".

Wiadomość z XV. wieku (Stefan Vrtel-wierczyński: Wybór tekstów staropolskich. Czasy najdawniejsze do 1543. roku. Lwowska Bihlioteka Slawistyczna. T. XII. 1930. r. 117.): „Ale ya nye 
wyem, maly thą macz s prawa dacz gey (jej) tho wyano". Tamże (120): "Ten szye ma odprzyszancz podlug prawego prawa".

$\mathrm{Z}$ tegoż czasu $w$ ortylach magdeburskich. (A. l. B $\mathrm{r}$ i ckner: Die Magdeburger Urtheile. Ein Denkmal deutschen Rechtes in polnischer Sprache aus der Mitte des XV. Jahrh. Archiv für slavische Philologie. Berlin. 1876. ed. Jagić. VI. 389.): „Prawo nalazlo ysz gy ma polozycz".

Wiadomość z drugiej polowy XV. wieku. (E mil Kałużnicki: Kleinere altpolnische Texte aus Handschriften des XV, und des Anfangs des XVI, Jahrh.: Sitzungsber. der philos.-hist. Classe d. Kaiserl. Akad. der Wissenschaften. Wien. C1. 1882. 279.): „Thego Yezusza... przykazuyemy y podlug prawa sakrazuyemy, aby gwozdzmi zelaznymy na krzyzu byl przybyth"

Zapiska z 1463. roku (Sylwiusz Mikucki: Badania autentyczności dokumentu $W$ praktyce kancelarji monar'szej i sądów polskich w wiekach średnich: Rozpr. i Sprawozd. z Posiedzeń Wydziału Histor.-Filoz. A.U. LXIX. 257-359.): „Volo super iure satis habere, alias chczą (chcę) na prawye dosycz myecz (dosyć mieć)".

Wiadomość z 1464 roku z ksiąg sądowych warszawskich (Zapiski i Roty polskie XV. i XVI. wieku z ksiag sądowych ziemi warszawskiej. wyd. Wladyslaw Kuraszkiewicz i Adam Wolf $\mathfrak{f}_{\text {. }}$ P.A.U. 1950, r. Nr. 3066.): "Thom polozila wsitho (wszystko) w dzal (dział), czsom (com) myala sprawem polozicz". Tamże (Nr. 3066.): Iakom ya zadzyrzal Katarzynę Cząsa przeth posswem na thymi snaky, kthorem urzandowy ukazal daley trzech lath $w$ pokoyu, pothla katarzyninych". Tamże z 1472. roku. (Nr. 3066.): „Iakom ya nye byl pomycznykyem ku zabyczu oczcza (ojca) gych (ich) Blazeya gwaltem, anym skody udzielal iako prawo skaże". Tamże z tegoż roku (Nr. 2. 967.): „Listem czom prawem przeziskal ywecz (i więc) mą (mię) prawo wyązalo". Tamże z 1485. roku (Nr. 1-602.): "Iako ya ssbraczą (z braćmi) zarzyrzal dwa dzyaly podluk praw mych".

W 1484. roku w Regule Trzeciego Zakonu św. Franciszka (H. E opaciński: Prace Filol. Warszawa. IV. 714.) nakazano: „Wszelky (którzy) maya gymyenye (majątek) s prawa mayą udzielaczy (udziełać $=$ wy.konać) testamenth".

Wiadomość z XV, wieku (L a cjan Malinowski: Spis rzeczy z wieku XV Prace Filol. Warszawa. IV. 664.): „I tho czo by gyey (jej) kupyl gieschly (jeśli) podług prawa mogły byszmy kthemu (ku temu) przyszcz (przyjść)".

$z$ ksiąg sądowych zakroczymskich $z$ 1493. roku (W a cła $\mathrm{w}$ Aleksander Maciejowski: Historia prawodawstw słowiańskich. T. VI. Wypisy z ksiąg zalkroczymskich. Warszawa 1858. 127.): „Wedlug prawa thraczi czeszcz - ex iure perdet honorem". Tamże z 1500. ro- 
ku: „Ten czlowyek myal szwe tramy (stragany) y szklep daley przez rolk y dzyen besz prawnego nagabanya (upominania), a tho yest podlug prawa".

Stanisław Orzechowski w dziele: „Rozmowa albo Dyalog oko?o Exequucyey Polskiej Korony" z 1563 roku, pisal na str. B2. r.: „Exekucya iest ustawienie w rygę swą Korony Polskiey, wedle Praw y Przywilegiow Koronnych". F2. v.: "Iakoż Krol wedle Prawa a Prywilegiow Koronnych, pocznie Exekucyą swoią od Ortarza"; H4. v.: „Aby Krol ono kacerstwo karał, wedle Prawa swego Krolewskiego".

Tenze Stanistaw Orzechowski $w$ dziele $z$ 1564. roku: "Quincunx, tho iest wzor Korony Polskiey na Cynku wystawiony", zamieścił na stronie Aa2.v.: „Kacerzu, ia Polak mówię teraz z tobą - Królestwie Polskim y Królu iego, wedle Praw y Przywileiów i też zwyczaiów Polskich, przez Króla Polskiego, nam Polakom poprzysiężonych".

M a rcin Bielski w swej, „Kronice Swiata” (Kraków. 1564. 44. v.): „Według prawa będzie karan"; 63. v.: "To prawo krolewskie będzye nad wami"; 80.v.: (Księgi Salomona) „Ani też może prawem postępować z mocnym nad sobą"; 98. v.: „Homerus... Spisał księgi o sprawie a rządźye, tak w Rycerskich rzeczach, jako około prawa"; 99. v.: „W małżeństwo wedhug obyczaiu y prawa”; 109. r.: „Komuby sie krzywda zdala w prawie. Chcemy ich bronić i czynić to wedhug prawa”; 327.v.: „Thegoż roku posłali Czechowie do Polski o krolewica Wladzisława aby ich panem chcial być, dawszy mu artykuły spłsane okoto zachowania praw y obyczaia”; 330.v.: „Wneth po weściu dołożywszy się buły złotey, iako ich prawo iest (złota bulla Karola IV.), zgodzili się glosem iednosthaynym, obieraiąc $\mathrm{z}$ śrzodiku swego Rzymskiego Krola, y obrali Maximiliana”; 331.r.: „Drudzy cztherzey Ellektorow szli przed cesarza, niosąc ornamenta cesarskie, wedlug prawa złotey buły... Zathym cesarz ze wszystikimi książęty nowego Rzymskiego krola, na dom Rzymski, to iest na Ratusz prowadzili, tamże wedlug prawa złotey buły, kosztowny obiad przygotowano"; 334.v.: „Prawa zachowanie pilnieysze z leden drugiego porady"; 377. v.: „Ludwig krol Węgierski y Polski... Dobka s Kurozwęik Kasztelana Krakowskiego, a po Sendywoia s Szubina Woiewodę Kaliskiego y Starostę Krakowsisiego, kztore Gubernatory w Polszce uczynił. Ale ci według praw pisanych nie sądzill, iedno według widzenia swego czynili co chcieli". 392. $v .:$ "Oni nie byli nigdy wiernictwem oycu, ani tobie będą: a gdyście im prawem wyszym co kiedy roskazali".

乇ukasz Górnicki W „Rozmowie Polaka z Włochem o Wolności y Prawach Polski" (wyd. bez roku i miejsca), pisał: A3. r.: „Ale iest od tego prawo, które przydzie swą drogą, gdy obierzemy Pana.., 
ktory posłuszny prawa nie dla boiaźni, ale iż to posłuszeństwo rozumie bydź sobie, y drugiem zdrowe... Xiądz tym, iż mię patrzyć nje możesz z osiadłości ziemsliey, bo jey nie mam, ale patrz mię do persona, w moiem należnem duchownem prawie”; H3̈. v.: „Gdyż tak mowi Prawo".

\section{Prawne nagabanie, przegabane prawo, przeszlkoda prawna}

Wiadomoste $z$ 1500. roku. (Wacław Aleksander Maciejow ski: Historya prawodawstw slowiańskich. Warszawa. 1858. 127.): ,Tedy ma przythym zostacz podlug gych wysznanya (ich wyznania) y przythym tako gdzye ten czlowyek myal szwe tramy y szklep, daley przesz rok $y$ dzyen besz prawnego nagabanya, a tho yest podlug prawa".

Wiadomość z XV. wieku ( $\mathrm{J}$ a n Łos: Przegląd językowych zabytków staropolskich do 1543 roku. Kraków. A.U. 1915. r. 529.): „Legale impedimentum = przegabne prawo".

\section{Niegodne (niesprawiedliwe) prawo}

Wiadomośc z 1419. roku. (Adolf Mysłowski et Waclaw Graniczny: Matricularum Regni Poloniae Codices s. XV. conscripti: Monumenta Iuris. Pomniki Prawa. Varsoviae. 1912. II. 299.): "Isze wzal czitirzi woly kupne na dobrowolney drodze, ne ziskaw (zyskał) negodnim prawem".

Odstąpić prawa. wzruszyć prawo, skazić prawo, wzgardzić prawem, nie sluchać prawa

Wiadomość z 1434. roku z zapisków sądowych ziemi warszawskiej. (Zapiski i Roty polskie XV-XVI. wieku z ksiag sądowych ziemi warszawskiej: wyd. Wladyslaw Kuraszkiewicz i Adam W olf f. P.A.U. 1950. Prace Kom. Jęz. Nr. 149.): ,Jaco dorothca (Jako Dorotka) odstampiwsie swego prawa, dala dzewce dwadzescya kop posagu a ti ya obranczil na czassi (zaręczylem swego czasu) przed sandem - Jaco ya przitem bil, Eze dorothca odstampiwszi swego prawa dala dzewce dwadzescya kop posagu, ati Stanislaw obranczil".

Wiadomość $z$ XV. wieku (Stefan Vrtel-Wierczypski: Wybór tekstów staropolskich. Czasy najdawniesze do 1543. roku. Lwowska Biblioteka Slawistyczna. T. XII. 1930.r. 119.): „Gdy... then radcza by odstappyl radesz y prawa... a przystąpyl sz brony ąbronyą ręką ku swemu przyraczelowi y przyszywayącz (przyzywając) gynych (innych) 
naprzeczywko prawu, ku ktoremu przyszągl (przysiagl), czo ten z to ma czyroyecz (cierpieć)".

Marcin Bielski w swej „Kronice Swiata” z 1564, roku: 101. v.: „Przyjąl Tullus laskawie Albany nie wzruszając ich praw”; 103. v.: „Wszakże im takież prawa wzruszył, iako y drugim”; 121.v.: „Szedi polym (Likurgus) do Azyey, tam się praw znamienitych nauczył. A gdy sie wrócil do oyczyzny Spartany albo Lacedemonu, nauczyl y ustawil miastu prawa ktorych przed tym nie mieli, stąd ubostwo było udręczone. A gdy przyięli ty prawa ,przywiódl ie ku przysiędze iż nie mieli onych praw wzruszać aż zasię przydzye. Szedr potym do Delfu pytać boga Apolina dobreli prawa a trwałe ustawił w oyczyznie. Który odpowiedzyał, iż dobre i słuszne. Odszedszy zabił sie sam, aby ty prawa wiecznie trwały w Lacedemonie"; (W czasie zamieszek religijnych w Niemczech:) 226. r.: „Książęta niekthore, pod pokrywką s. Ewangeliey, wiele rosthyrkow czynia prawa niesłuchają, kanności nad sobą niechcą mieć”; 230. v.: „Stey przyczyny, iż na on czas krolowie Polscy z Mazowieckiemi książęty, $w$ ten obyczay, y tym prawa... prawem byli posthąpili Pruskiej ziemie zakonowi, kthory zowia niemiecki... ale oni złomiwszy swoje prawa y ugody... gdyż nikt inny na nie prawa y mocy niema".

Stan islaw Orzechowski w dziele, „Rozmowa, albo Dyalog około Exequucyey Polskiey Korony", z 1563. roku, pisał na str. S2. r.: „Co gdy to wszystko $w$ sobie Statut Alexnadrow ma słusznie skażony y wymazany z Statutu praw Polskich być ma, iako Rzeczypospolitey naszey bardzo szkodliwy". Mowa tu o statucie króla Aleksandra Jagiellończyka.

Eukasz Górnicki w dziele „Rozmowa Polska z Wlochem o wolnosiciach y prawach Polsiki." (wydanym bez oznaczenia roku i miejsca), pisal na str. B1. v.: ,Za wszeteczeństwem nastaie wzgarda prawa... także y owa nowa Constitucia, ktoraście znieśli stare prawa $z$ strony ruszenia pospolitego... Bo za tamtem starem prawem y sposobem wzorowania waszych przodków".

Mieć ku czemu prawo, nie mieć prawa

Wiadomość z 1395. roku z ksiąg grodzkich z Pyzdr w Wielkopolsce (J. Lekszycki: Die ältesten grosspolnischen Grodbucher: Publication aus Preussischen Staatsarchiven. Leipzig. 1887-1889. II. No. 1773.): „Iszem bil poszlem... do tich, czo k temu prawo maią".

W zapiskach sądowych grodzkich i ziemskich wielkopolskich z 1401 . roku (Franciszek Piekosinski: Studia, Rozprawy i Materialy z dziedziny Historyi Polskjiej i Prawa Polskiego. VI. Kraków. 53.): 
„Vęcencia (Wincencja)... k temu prawa ne ma”. Tamże (215.): „Any ssnopa dawal, any $\mathrm{k}$ nemu prawa mal (miał)". Tamże (309.) z 1404. roku: „Iszem ne pobral penandzi (pieniędzy) $k$ ginsze (ku nim że) on prawo mal".

$\mathrm{Z}$ ksiag ziemi warszawskiej z 1470. roku. (Zapiski i roty polskie z XV-XVI. wieku z ksiąg sądowych ziemi warszawskiej. wyd. W ładyskaw Kuraszkiewicz i A a m Wolff. P.A.U. r. 1950.: Prace Kom. Jęz. Nr. 251.): „Iako nam prawo... sluzhi (służy) szprzotkowych ( $\mathrm{z}$ przodków) nasych, yalko y oyczy naschemu (ojcu naszemu) nyegdi (niegdyś) Andrzeyowi... nye odpowyedacz na roczech (rokach) pospolithych, tylko na xazączych (książęcych). Thako my pomozy bog... Iako tho wyem jech ony prawo". Tamzie (Nr. 2. 948.): „Iakom ya gwaltem ssamowtr (! samowtór) nyesbyl Jana gdi przigechal do mlyna na kthori młyn prawo ma mlecz zitha". Tamże: (Nr. 2925.) z 1468. roku.: „Ląky nakthora prawo ma". Tamże (Nr. 1645.) z 1490. roku.: „Iako mam prawo na brzek (!) Rzeky Jezorey sluzancze".

Eukasz Górnicki w ,Rozmowie Polaka z Włochem o wolnościach y prawach Polski”, pisal na str. L.1.r.: „A nie miał pozwany wymowki żem niewiedział o pozwie y przewodzie prawa... procuratorowie żeby nie mieli mieysca u prawa stania".

Prawo sadzić, konać, stosować, być pod prawem, domódz si ęprawa itd.

Zapiska z 1407. roku (Biblioteka Warszawska r. 1861. III. 17.): „Iaco to swatczimi iaco czy (ci) ludze priwo (pierwej) sbegli swym dobitkem, nyszli nane (na nie) wlodarza szadzono prawo".

Wiadomość z 1447. roku z Mazowsza (Kazimierz Tymieniecki: Sądownictwo w sprawach kmiecych, a ustalenie się stanów na Mazowszu pod koniec wieków średnich. Poznań. 1922. Pozn. Tow. Przyj. Nauk. Prace Kom. Hist. T. III. 135.): „Nicolaus.:: egit super et contra Stanislaum... dlicens, quia tu cittans meos duos kmethones... et super eos wlt (vulit) ius adfinire, alias prawa conacz, et Stanislaus... dixit et respondit: circa istius nolo ius super eos... adfinire, alias conacz na nye prawa, quia tu me intrudistis in ius Chulmiense... et ego in isto iure molo agere... sed in terrestri iure".

W wyrokach Sądów Miejskich, czyli Ortylach (W. A. Ma c i e jowski: Historia prawodawstw słowiańskich. T. VI.: Wyroki sądów miejskich czyli ortyle. 128.): "Czyly odpowyadacz ma thu poszthawycz szwego zachoczczą przed prawem, gdzye szye kona", czyli wykonuje.

Wiadomość z Mazowsza z 1471, roku. J. K. Kochanow ski: Próba ujęcia hermeneutycznego pojęcia o ziemi i obyczaju, ussięciu 
i przywileju $w$ świetle praktyki sądowej na Mazowszu, u schyłku wieków średnich: Posiedz. Tow. Nauk. Warsz. VIII. 2. 34.): „Swiętochna.. mya (mię) poslala do cancelaryey ku wysluchanyu wsdanya gymyenya (majątku) na Lypnykach, kthorego prawem pozyskala na Stanislawye".

W ortylach z XV. wieku (E mil Kałuźnicki: Kleinere altpolnische Texte aus Handschriften des XV. und des Anfangs des XVI. Jahrhundertes: Sitzungsberichte der philos.-hist. Classe d. K. Akad. der Wissenschaften. C1. Wien. 1882. 141.): „Kthory ortel myedzy thyma dwyema moze ostacz is prawa".

Marcin Bielski w swej „Kronice Swiata” (wyd. Krakow. 1564. 195. r.): „Pisal Luter... chee być pod posluszeństwem y prawem iego zawdy".

Stanisław Orzechowski w swym dziele ,Quincunx, tho iest wzor Korony Polskiej na Cynku wystawiony", z 1564. roku: B2. v.: "Nie zostanieli ieszcze iaka między nami w Polszce przyczyna niezgody, która przez Exekucyą miela by być wszystka z Polski wykorzeniona, ieśli chcemy $\mathrm{z}$ sobą $\mathrm{w}$ mierze, a $\mathrm{w}$ pokoju wedle Prawa pod iednym Królem w Polszce żyć”. B3.r.: „Gdzie ludzie iedney wiary, iednego Prawa, za Zwierzchnością Kapłańską pod iednym Królem w Królestwrie nie są"; B4.r.: "Y iaciem też przeto opuścil to Seymowe Prawo"; V4.r.: "Naprzód Zwyczayem, potym Prawem Polskim a na koniec Kościoła Bożego świadeotwem"; V4. v.: „Tedy ten Krol... był przeciwko Prawu, y przeciwko zwyczaiowi Krolestwa Polskiego Krolem Koronowanym?".

Znów Orzechowski w „Rozmowie, albo Dyalogu około Exequucyey Polskiej Korony”, z 1563. roku, pisal: E1.r.: „Wszystkie Prawa y Prywilegie swe, iakom ci iuz powiedał, ku tym trzem rzeczom stosowali... Prawo pospolite ku miłości Braterskiey stosuiąc, wedle Prawa, poprostu bes Prokuratorow, ieden $\mathrm{z}$ drugim żywiąc, $\mathrm{y}$ nic innego Prawo u niech nie było Regula iaka, ktora dobrzy Mnichowie żywią, w Klasztorze: albowiem Mnich aby z Zakonu niewystapił, sprawuje syę Regułą. Tak też przodkowie naszy, aby niwczym ex isto Triangulo niewykraczali, sprawowali sye Prawem pospolitym. W Polskie Prawo Reguła iest życia”; T4.r.: „Norymbergczanie do Wenetów posłali prosząc ich, aby Wenetowie im sposob y Prawa Rzeczypospolitey swey przysłali... Nie wstydzil sye Rzym XII Tabulas od Athen wziąć, y też Prawem obcym swą Rzeczpospolitą rządzić; V3.r.: „Ale Prawo w Polszce u nas iest że bes Krola na woynę iechać nie mamy"; R1. v.: "Niemożesz sye y. Prawem więcey na Krolu domoc, rzeczeć Krol, com z tobą zmowil, toć daię". 
W znaczeniu ujemnym: „Prawa wymyślac”

Wedle „Kroniki Swiata" Marcina Bielskiego (za czasów reformacji): 419.v.: „Gdańszczanie nowe rzeczy sthroili, wiarę y prawa sobie insze wymyślali".

\section{Prawo przyrodzone, czyli prawo natury, prawo człowiecze}

Wiadomóść z 1474, roku (Ja n E oś: Przegląd językowych zabytków staropolskich do r. 1543. Kraków. A.U. 1915. 540.): „Ninye gy maią, dzirszą (dzierżą) y chowayą za czesnego y falonego cloveca (czlowieka), caco (kako $=$ jako) wele (wiele) czlowecze przyrodzene posząda (pożąda), y kako przysłusza (przysłuża) prawo clovecze"

Wiadomość $z$ około 1450, roku ( $\mathrm{L}$ u d w ik Berna cki: Najdawniejszy pomnik katechizmu polskiego: Pamiętnik Literacki. Lwów. IX. 318.): „Tho iest prawo przyrodzone, pospolu sz lyudzmy (z ludźmi) stworzone".

W ,Kronice Swiata" Marcina Bielskiego, wedle krakowskiego wydania z 1564, roku, str. 53. verso: „Ruth... Wzięla potym. ięczmień a doniosła do świekry, a powiedzyała iey wszystko co sie dzyało. Rzekła świekra ,poczekay mało, coć rzekł nie uczyni inaczey. Siadl tedy Booz w bronie mieyskiey, a gdy uyrzal bliższe w rodzye Ruth, zawołal go $\mathbf{k}$ sobie imieniem rzekąc, siądź tu troche, w uczynil tak. Wezwal Booz dziesięć mężów starszych miejskich, przed ktoremi ku bliskiemu krewnemu mówił: Brata naszego Elimelecha żona Noemi przedaie imienie, ty bliskość $\mathrm{k}$ temu przyrodzonym prawem maiąc, chcę to od ciebie słyszeć przed wszystkimi, ieśli ie odkupisz, albo nie, abowiem nie masz bliższych do niego nad ciebie. Który rzekł, ia role odikupię. Rzekł Booz, gdyż rolę mieć chcesz, wźnisz Ruth, Moabską za żonę, aby wskrzesić plemię nieboszczyka Elimelecha, na twoiey dzyedzinie. Usłyszawszy to rzekł, ustępuię prawa, to iest spuszczam ci bliskość swoię. Był then obyczay u nich, gdy kto komu prawo przyrodzone spuszczal, trzewik albo bot ziął z nogi, a podał stronie, na znak iż $\mathrm{mu}$ ie ze wszystkim prawem spuszcza. A gojy tak uczynil, oświadczył Booz wszystkim, iz biorę Ruth Moabską za żonę sobie". To opowiadanie zaczerpnięto ze Starego Zakonu z Księgi Ruth. Słowo "prawo" przytacza w tychże samych miejscach Wujek.

A dalej u Bielskiego 61.v.: „Przed Trojańską walką mało nieco lat była walka ieszcze okrutniejsza niżli Trojańska międ'zy dwiema braty $w$ Grecyey, na które to królestwo przypadalo przyrodzonym prawem... Po nim był Monnerius, tez prawa y pobor Brytannom ustawil, y koronę sam sobie złotą na glowę włoży"; 120.v.: "Klaudyus 
brata Hasdrubala dał ściąć, iż sie nad lego wolą potykał z nieprzyiacielem, potym glowę noszono po woysku wołaiąc, iż żadne prawo nie folguie przyrodzonym”; 198.r.: „Adrian Papież... przeciw tym, ktorzy Papieża nie są poshuszini, ani za iego prawy postępuią... wszystko spadło prawem przyrodzonym na Karła wnuka po czocce (ciotce)... lacno moga Lutera iako tego, kthory wzgardzyl boże y ludzkie prawa zwyciężyc"; 213. v.: „Księgi trzecie Melanktonow, ktore zowią Loci communes Teologici, y Papieża też powiadal być niebyć pirwszego prawem Bożym, ale luckim"; 236. r.: "Czego Boże y ludzkie prawo broni"; 363. r.: „Wracisław umarł. Mszczuy dochodzić Gdańska chcial prawem przyrodzonym po bracie”; 363. v.: ,Ziechali sie do Opawy Bolesław książę Krakowski z Przemyslawem Czeskim krolem ugadzać się o księstwo Opawskie... Książe zasię powiadał być ten powiat żawżdy ku Polszce przyrodzonym, nie mógł go brat moy nieboszczyk Opolskie Książę żadnym prawem od Polskiego krolestwa oddalić"; 364.v.: "Przemysław Poznańskie Książę zstąpił mu z Rudskiey ziemie, kthora dziś zową Wieluńską, mieniąc ią być $w$ iego prawie"; 366. v.: „Po śmierci Lestka czarnego przypadło księsthwo Siradzkie na Eokietka brata lego, na ktorego też sprawiedliwie y Monarchia Polska po bracie prawem przyrodzonym przypadała”; 367.v.: „Po nim został Kazimierz porażon. Eoktek Eęczyckim książęciem prawem przyrodzonym gdy potomka nie mial"; 407. v.: „Y poganinowi ma być słowo chowane prawem wszystkich ludzi".

Łukasz Górnicki w "Rozmowie Polaka z Włochem 0 wolnościach y prawach Polski”, pisal: E2. v.: „Do zgody prawo zmierzać ma. Prawo iest rozumne, postanowienie ugruntowane na przyrodzeIniu”; Gl.v.: „A nie tak sie mowi, żeby ta słuszność miała przodkować, bo też iest co y prawo... tedy słuszność prawo kierując, sprawiedliwość czyni doskonalszą... słuszność zamyka się pod prawem przyrodzonem, a sprawiedliwość pod prawem opisanem. Więc iż prawo opisane nie mogło wszystkiego oblapić, co się między ludźmi trafia... gdy tam gdzie $w$ sprawie czego nie dostanie, albo prawo ku niesprawiedliwości, a krżywo byloby ciągnione, on nastawi, a krżywość onę naprostuie, a to będzie słuszność, to iest praw pisanego prostowanie, bo y ten to prawo napisal, gdyby na świecie był, toby uczynił".

\section{Prawo pisane, w przeciwiensstwie do zwyczajowego}

Marcin Bielski w swej "Kronice Swiata” (Kraków, 1564.): 212.v.: „Papież posłał Wergeriusza zasię do Niemiec y do wszystkich książąt, aby wielkie Woncilium zlożyli w Mantue, aby sie też wywiedział od Luteranów, co za Artykuły podadzą, abych takie prawa, kondicia y ustawy spisał y dał im, iżby niepszyiechali". 
Eukasz Górnicki w "Rozmowie Polaka z Włochem o wolnościach y prawach Polski" na str. E1.r.: "Wloch: Naprzod to powiedam, iż nowe są rzeczy w Polszce pisane prawo"; F1.v.: "Nie samem Prawem pisanem sądzone bydź ma. Y prżeto nie samem tylko pisanem prawem lud sądzon bydź ma... y tak ma kierować pisane prawo, ku zdrowiu tych, ktorzy do sądu prźychodzą. Bo prawo pisane chocia dla sprawiedliwości iest wyrażone, nie może tego ze wszysthie stron obwarowac... Prawo pisane to żawdy iednakie iest, a trefunki, przygody, chytrośći ludzie, te zawżdy a zawżdy inaksze są... nie psuiąc pisanego prawa, tak go uźywać ma, iż by ten zawżdy wygrał, kto sprawiedliwą... bo ci subtelne, a ku swey rzeczy prawa wykładać umieią, aby sprostość prawa, chytrością wynicowali... okolo prawa, tam iest nayszkodliwsza, tam iest iadem $y$ trucizną. $Y$ niskąd inąd nie idą tak gęste u was morderstwa, iedno z tego waszego dziwnego prawa... pomniąc zawżdy na to, iż prawo ludzie stanowią, dla sprawiedliwości, żeby się do prawa stosuiąc nie sprawiedliwie sądzić mialo"; F4. r.: "Iż nie może barżiey patrzyć słuszności, y prawa Sędzia nad dwiema, ktore sądzi, iaki ociec patrzy sądząc między syny swemi... Ale we Włoszech u nas, zasz nie masz prawa?... a gdyby iako z regestru szukal na każdą rzecz pisanego prawa, nigdyby dobrże nie osądził... Coś też powiedział iż z naszego dziwnego prawa mężoboystwa rostą, może się $y$ to trafić, że kto nie pilnuiąc prawa, y lekce ie sobie ważąc, maiętność traci, potym zaboje onego co pilnował prawa, a wygrał: ale nie prawo nasze prżyczyną iest mężoboystwa"; G1.v.: "Słuszność zamyka się pod prawem przyrodzonem, a sprawiedliwość pod prawem opisanem, więc i prawo opisane nie mogło wszystkiego obłapić, co się mię'dzy ludźmi trafia... gdy tam gdzie w sprawie czego nie dostanie, albo. prawe ku niesprawiedliwości, a krzywe byłoby ciągnione, on nastawi, a krzywoś oną naprostuje, a to będzie słuszność, to jest prawa pisanego prostowanie, bo $i$ ten kto to prawo napisal, gdyby na swiecie byl, toby uczynil".

\section{Duchowe prawo kościelne}

Wiadomość z Mazowsza z 1447, roku: „Xąncz Jan wyszval... cowalya (kowala) o pothkowe w duchowne prawo" (J.K. Kochanowski: Próba ujęcia hermeneutycznego pojęcia o ziemi i obyczaju, księciu i przywileju w swietle praktyki sądowej na Mazowszu u schyłku wieków śređnich: Sprawozdania z Posiedzeń Tow. Nauk. Warszawa. VIII. 2. 41.).

W rękopisie Nr. 43. Biblioteki Kapitulnej we Wroclawiu z polowy XV. wieku (Jerzy Woronczak: Prace Wroclawskiego Tow. Naukowego 1956. rok. Nr. 106.), do slów: „Nullo decreto apostolico, 
nulloque sacro canone institutum", glossa: "potwierdzeniem prawem ust(nowione)".

Wiadomość z Księgi ziemi czerskiej z 1480. roku. (wyd. T. L ubomirski: Liber terrae Cernensis. Warszawa. 1879. XXXVII.): "Wloki (w’óki) na kthore pleban Praszmowski prawo ma".

W Zapiskach i Rotach polskich z XV. i XVI. wieku, z ksiąg sądowych ziemi warszawskiej (wyd. Władysław Kuraszkiewicz I Adam Wolff: Prace Kom. Jęz. P.A.U. Nr. 36. r. 1950. Nr 2: 979.): „Iakom ya kmecza Jana do pythanya praw wszloky (prośby o prawo zwloki), anych go ssamoschoszt (samoszóst) wząl gwalthem szdochodi ( $z$ dochodami) kxanximy (księżymi)" Tamże (Nr. 1544.): „Yako ya tho wyem ysze bartholomeus (Bartłomiej) xandza opathow nyezastal drzew u kmyeczy w mogich (w moich) nowego rąmbyenya y czastokrocz szkody nye dzalaly, anym go gonyl sobye nyerownymy thedy do mye prawa przyyechal zadacz (żądać)". W Regule trzeciego zakonu św. Franciszka z 1484. roku. (H. Eopaciński: Prace Filol. Warszawa. IV. 714.): „Braczya y siostry... mayą mowiczi syedmy godzyn od prawa duchownego wsthavyone: W przekładzie polskim Kodeksu Swiętosławowego (wyd. Franciszek Piekosiński w Archiwum Kom. Prawniczej. Collectanea ex Archivo Collegii Iuridici. A.U. III. 9): „święte prawa" użyte $w$ znaczeniu canones: „Podług swanthich praw myanowanye zachoczcze w grzeszkach nye ma myesczcza":

W Kazaniach Swiętokrzyskich (Al. B r ückner: Drobne zabytki języka polskiego z XV. wieku: Rozpr. i Sprawozd. z Posiedzeñ Wydź. Filol. A.U. XXV. 155.): „Iura parochialia - prawa kosczelnya”.

Marcin Bielski w swej, „Kronice Swiata" (Kraków. 1564. 131. v.: „Prawo kościelne, aby było rychło wrocone, bowiem kościoly połupione, ani w tym trzeba prawa używać”; 213. r.: „A też Papież nie nieopuści prawa swego"; 220.v.: „Koncilium w Trydencie zlożono tam... Papież... rozkazuye przyiechać, tym ktorzy $\mathrm{k}$ niemu przysluszaią w prawa Patryarchom, Arcybiskupom, Biskupom, Opathom, y innym, ktorym wolno będzie każdemu snich swoie zdanie powiadać"; 217.r.: „Na Seymie w Frankforcie takie postanowienie uczynili... na ktorych byli Rzymscy kapłani przewiedli prawo o-koscielne dochody"; 225.r.: „Duchowieństwo y Kollegium Kolońskie posthępowali w prawie Duchownym swego Arcybiskupowi w Rzymio”; 234.v.: „Prawa y ustawy trzymal, ieśli sie mu trafi być Papieżem... Czytaią przed nim prawa albo przywileje iako sie zachowuie"; 238.v.: „Ustawiła takie prawo koscielne, aby żadny Biskup niechowal kaplanów żonatych"; 239. r.: „Arcybiskupstwo Medyolańskie odzierżał nad prawo pierwsze Ferarskie Kardynała, gdy sie prawowali przed Papieżem $w$ nie"; 356. v.: „S. Florian przywiezion do Polski tym obyczaiem. İ posłał był Krol 
Kazimirez do Papieża Luciusa trzeciego posły swe z porady Getki Biskupa o pothwierdzenie praw, zwłaszcza duchownych, przez ktore posły roskazał prosić oyca Papieża o iakie kości świętych”; 393.r.: „Prawa Papieskie, ten sobie wyprawił prawo na toż Biskupstwo u Papieża... gdyż tho prawo tylko samemu Krolowi służy".

Stanislaw Orzechowski w dziele "Rozmowa, albo Day$\log$ około Exequucyey Polskiej Korony" z 1563. roku, mówiąc o prawach prymasa gnieźnieńskiego wyraził się: F2. $r_{0}$, „Niech patrzy na Kapłana onego, ktory go posadził na Stolicy Krolewskiey, ieśli iemu nie viął tego, albo viąć niedopuszczał z Prawa własnego lego". (Następnie o prawach ogólnych biskupich): H4.v.: „Biskupowi... należy definire, iż to iest Heresis, a potym onego Prawem przepartego, ieśliżeby syę kaiać nie chciał, zakląc, a gdzieby y na klątwę niedbał, Krolowi oznaymić, aby Krol ono kacerstwo z urzędu swego Krolewskiego karal, wedle Prawa swego Krolewskiego"; J1.r.: „Prze tę przyczynę Duchowne Prawo klątew Sądu swego”; K1.v.: „Prawo swe utracił, nadania mu pobrano"; K2.r.: „Krol to obaczy ieśli Prawo Polskie broni przed Arcybiskupem plugawie mowić, a coż Arcybiskupa hańbié".

Tenże Orzechowski w dziele "Quincunx, tho iest wzor Korony Polskiey na Cynku wystawiony” z 1564. roku: C4.r.: „Przyznay Arcybiskupa, wedle Praw y Przywileiów Arcybiskupa Gnieźnieńskiego, Kapłana Rzymskiego, Koronatora Króla Polskiego ia tobie pokazuję... Wypędzasz Koronatora Króla Polskiego, Prawy y Przywoleymi Polskiego Krolestwa uprzywileiowanego"; J1.r.: „Dobrze to bacze y pomnę, że prze tę przyczynę Duchowne Prawo klątew Sądu swego nazywa Medicinalem Excommunicationem".

Eukasz Górnicki w "Rozmowie Polaka z Włochem o wolności y prawach Polski" pisak: D1.v.: ,Trzeci on brat co daleko mieszkal, dowiedziawszy się, iż brat zabił, przyiechał do domu, y chcial - to prawem czynić... odsyła ziemski urząd do prawa duchownego"; K2. V.: „A gdyżeście zarżucili prawo duchowne, ktore barżo potrzebne było. Więc niechay $w$ Statucie będzie to pierwsze prawo ktore do porżądnie, a iednostaynie chwalenia Boga... należy..."

\section{Prawo magdeburskie, niemieckie, miejskle}

Wiadomość z 1398, roku z najđawniejszych ksiąg/sądowych ziemskich krakowskich (Antiquissimi libri iudiciales terrae Cracoviensis. ed Boleslaus Ulanowski: Starodawne Prawa Polskiego Pomniki: T. VIII. 6574.): „Pattek... meseczkego brawa (sic!) ne przymowal, any te mesczkym (tj. miejskim) prawem obchodzil". Zapiska z tegoż 
roku Biblioteka Warszawska. r. 1861. T. III. 23.): „Iaco (jako) w Iedliczi bila nemeczke prawo, ale sginaul przywiley".

Zapiska z 1437. roku z ziemi sanockiej (Akita Grodzkie i Ziemskie z czasów Rzpitej Polskiej, z Archiwum Bernardyńskiego we Lwowie. Najdawniejsze zapiski sądów sanockich. T. XI. 128.): „Sub ius supremum, vulgo pod wissy prawo", czyli wyżny sąd magdeburskiego prawa.

Wiadomość $z$ Mazowsza $z$ 1443, roku. (Kazimierz Tymien le cki: Sądownictwo w sprawach kmiecych, a ustalenie się stanów na Mazowszu pod koniec wieków średnich. Poznań. 1922. 133.): „Iako ya nye przybyegl do schy (wsi) Ianowej... any.. mlynarza, na kthorego prawo polskye y myemyeczskye ossadzyl, s prawa yego gwalthem se schy wybyl".

Z Kodeksu Swiętosławskiego z około 1450, roku (Tłumaczenie polskie Statutów Ziemskich. wyd. Franciszek Piekoński: Archiwum Komisji Prawniczej U.J. Collectanea ex Archivo Collegii Juridici. 14.): „Zaluyącz (żałując, czyli podając skargę) w prawye nyemyczkem przeczywko krzywemu ( $t j$. winowajcy), gemu thymsze prawem othpowyedzecz nye powynyen... O pozegę prawem myesczkym, alybo nyemyeczkym we wszaach (wsiach) nye będą szę mocz wymowicz".

W Słowniczku łacińsiko-polskim wyrazów prawa magdeburskiego z Xv, wieku (Objaśnił Zygmunt Celichowski: Poznań. 1875.): „Dictur edictum iudicium wlgariter przykazany sąd wysschego prawa pod klanthwą krolewską. Comes grabya vel woyth wyszschego prawa".

Podobnie jak ta wiadomość, nestępne pochodzą też $z \mathbf{x V}$, wieku, bez oznaczenia roku. I tak wedle zapiski Jana $\mathbf{L}$ osia (Przegląd językowych zabytków staropolskich do 1543, roku. A.U. rok 1915 526.): „Municipale ius - powyszone prawo", czyli wyższy sąd prawa miejskiego. Tamże (528.): „Ius municipale - myeszczkye prawo". Tamże (528.): „Burgrabius supremus castellanus, nawyssy sandzya grodszky prawa wysokyego. Comes grabya vel woyth wyssego prawa".

Zapiska z ksiąg ławniczych przemyskich (Monumenta Premisliae Historica Librorum Scabinalium. wyd. Jan Smolka i Zofia T y m ińska. Przemyśl, 1936. T. II. Nr. 963.): „Andreas... posuit solidum, quia Kosth aprobavit iuratorem iuris maydburgensis benivole, alias dobrowolne ssa pusczil w prawo meydeburskye, huius civitatis, obmittendo suum ius terrestre, pro equo, aput ipsum arestato".

W Kodeksie Dyplomatycznym Wielkopolskim (Codex Diplomaticus Maioris Poloniae. str. 307. Nr. 346.): „Tertium denarium iuris civitatis, alias meske (miejsikie) prawo".

$\mathrm{Z}$ wyroków prawa miejskiego (Emil Kałużnicki: Die polnische Recension der Magdeburger Urtheile: Sitzungsberichte der philosophisch-hostorischen Classe der $K$. Akad. der Wissenschaften. 
Wien. 1886. CXI. 137.): „Przyszasznyczy (przysiężnicy, czyli lawnicy) mayą gyne (inne) przyszasznyky wybyeracz... a gest prawo podlug Maydeburskyego prawa... Szoltystwa... czo... leszą w marborskyem prawye, thyto leszą y szluchayą lyensky (lenne) prawo".

Wiadomość $z$ tegoż czasu (Józef Przyborowski: Vetustissimam adiectivorum linguae Polonae declinationem, monumentis ineditis illustravit. Poznań. 1861. 12.): „Pani Zophia z nemeczskyego prawa wysla... any sza dobrowolne w prawo nemeczkye dala".

W glosach polskich wpisanych do lacińsko-niemieckiego słownika z 1490, roku. (Boles law Erzepki: Przyczynki do średniowiecznego słownictwa polskiego. I: Rocznik Tow. Przyj. Nauk Poznańskiego. XXXIV. 77.) slowa: „Emphiticum ius", oddano przez: „Nyemyeczskye pravo".

Eukasz Górnicki w „Rozmowie Polaka z Wlochem o wolnościach i prawach Polski", wkłada w usta Wlocha rozmawiającego z Polakiem, str. E4. r.: „Y Magdeburskie prawo, które się też Czartu godzi ,niech prży nich zostanie: ale ia mowię o Szlachcie, y dziwuię się, czemuście na się tak głupie postanowili prawo"; F3. v.: „W Niemieckiem ci to tylko glupiem prawie... nie każą sądzić iako wie Sędzia... a więc tym ma stracić rzecz swoię, iż czego potrzebnego abo on, abo procurator iemu $z$ prawa dany nie dołożył?... a ina Sędzia ktory rowno sobie sądzi, y podług prawa sądzić winien"; L4. r.: „Krolowie aź do Niemiec po Iudzie słali, a Niemcy prźyść tu niechcieli aź z swoim Megdeburskiem prawem... wszystek porżądek, y prawo wasze ku rycerskiem rżeczom zmierża".

Marcin Bielski w swej, ,Kronice Swiata”, wydanej w Krakowie w 1564, roku, tak pisał o sprawie Tęczyńskiego, zabitego w kościele franciszkaniskim przez mieszczan krakowskich w czasie, gdy Kazimierz Jagiellończyk prowadził wojnę z Krzyżakami: 393. v.: „Na drugi rok pozwani byli Rayce Krakowscy przed Krola na wigilią trzech krolow, ktorzy prosili na roku aby byli sądzeni prawem Niemieckim przed Wotem według ich przywilegiow. Krol z Radami swymi powiedzyał im, iż nieboszczyk Tęczyński odzywał się też swami na to prawo, a niechcieliście mu go złożyć, iedno bez prawa y zachowania haniebnie zabić".

\section{Prawo chelmińskie dla miast na Pomorzu}

Wiadomość z Mazowsza $z$ 1458, roku. (K a zi mi er z T y mieniecki: Sądownictwo $w$ sprawach kmiecych a ustalenie się stanów na Mazowszu pod koniec wieków średnich. Poznańskie Tow. Przyj. Nauk. Prace Kom. Hist. T. III. zesz. 136.): „Pyotr nye sandzyl Pyotra polskym prawem, ale chelmynskym". 
Prawo w opłotki swe zawrzeć może, czyli objąć swym zasięgiem

Eukasz Górnicki w, Rozmowie Polaka z Wlochem o wolnościach y prawach Polski”; B3. r.: „Przecię tego twego podobania, nie maią korować zmysły twoie, lecz doskonaly rozum, a nie rozum lednego czlowieka, ale rozum powszechny, to iest prawo, ktore to prawo w pewne oplotki Wolność zawarło, iżby się to nie czyniło, co nie przystoi, y żebyś tak szafował tą twoią Wolnością, iakoby tez drudzy używać ley mogli, a twoia Wolność żeby drugim niewoley nie czyniła. Jakosz prawodawcy tem trzem rzeczam stanowiąc prawa, dogadzać zwykli: jako szanować Wolność. Prawodawcy czemu dogadzać maią... Pierwsze, iż by ona Rzeczpospolita, ktorey daią prawa, była wolna”; El. v.: „Á் za Zygmuntow, Oyca y syna, gdy ludziom nowe zasmakowało prawo, a stare mierznąc poczęlo, chęć też do nabywania maiętności przystąpiła, dopiero się rozszeryl (sic!) Statut y Constitutie piastować poczęlo. Ale iakom ia słyszał od ludzi starych, daleko więtsza była sprawiedliwość w Polszce, poki nie było pisanego prawa, a zgoda, miłość między ludźmi gorętsza, niźli ią widzimy teraz, gdy prawo pisane nastało. Iakoż iż niektore rzeczy, prawo $w$ oplotki swe zawrzeć może, a niektorych nie może, zdawna między ludźmi wątpienie iest co lepiey, ieśli, pod prawem żyć, czyli pod władzą człowieka cnotliwego y mądrego, ktoryby był miasto prawa, y może dosyć slow bydź na obie stronie".

\section{Super ius, czyli nad prawo, niezgodne z prawem}

Wiadomość z XV, wieku z lubelskiej księgi podkomorskiej. Podkomorzy był $\mathrm{w}$ Polsce sędzią $\mathrm{w}$ sprawach granicznych. (Lubelska księga podkomorska piętnastego wieku. wyd. Leon Bialkowski. Tow. Nauk. Katol. Uniw. Lubel. T. I. r. 1934. str. 99.): „Circa quas granicies circa primum scopulum (tj. miejsce wyniosle, kopiec, pogórek) et ultimum acialem, alias $w$ narosznycz, Johannes Schorcz ministerialis terrestris (tj. woźny podkomorski), primo, secundo, tercio, quarto, super ius, alias nad prawo, si quis haberet, ibidem aliquid ius, quod hodie non responderet, aut contradiceret, impost im perpetuum silentium haberet pro predictis graniciebus. Que granicies sic per nostrum camerarium limitate, stippate, terminate et erecte, debent stare, inviolabiliter im perpetuum esse". Podkomorzy wytyczywszy granice od kopca do narożnika, nakazał woźnemu, Janowi Szorcowi ogłosić czterokrotnie, że jeżeliby kto stwierdził, iż ktoś ma ziemię ponad prawo, ma to zgłosić, bo inaczej granica pozostanie niezmieniona na zawsze.

Marcin Bielski w "Kronice Swiata" (wedle krakowskiego wydania z 1564, roku), omawiając początkowe dzieje Rzymu, wyraził się na str. 100. $\nabla_{a}:$ „Nad prawo y zachowanie ich". Znów dalej, gdy 
cesarz Karol V. za swego życia przygotowywal elekcję brata swego Ferdynanda na króla rzymskiego, znaleźli się przeciwnicy, głoszący: 209. v.: „Przeciw prziwileiowi Karła czwartego króla wybierać Rzymskiego będąc sam ieszcze żyw, gdzie to iest przeciw prawu wolności Cesarskiego stolca, ieszcze iako słyszymy, bratha rodzonego Ferdynanda chce mieć krolem nowym... Książęta y miasta pisali Cesarzowi... dziwuiąc sie te, yż on to czyni nad prawo y obyczay"; 230. v.: (żona uwięzionego elektora starała się): "Jakoby męża mogła z więzienia wybawić, przetho prosiła wszystkich Książąt Niemieckich, aby mówill z Cesarzem iż nad prawo y nad przyrzeczenie więzienie cierpi, gdyż $z$ dobrey woley stanąl za przyrzeczeniem wolności, nad prawo tedy to cierpi".

Stanislaw Orzechowski w dziele Quincunx, tho iest wzor Korony Polskiej, na cynku wystawiony, z 1564, roku. E4. v.: ,Ale to iest Exekucya, która nachylone ku upadku Królestwo, w iego klóbę ustawia, u gruntów iego strzeże, Prawy i też Przywileymi przez Króla Polskiego nam poprzysiężonymi. Powiadaia pospolicie, iż to iest Exequucya, brać co komu nad prawo dane. Brać nie jest Exequucya, ale brać co komu nad prawo dano".

Prawnik $w$ znaczeniu iurista, legista i prolocutor, w prawie biegly

W kodeksie papierowym z początku XV, wieku $w$ Bibliotece Jagiellońskiej No. 1302 AA X 3: „Explicationes Antiponary et aliorum canticorum ecclesiae", na oprawie są rozmaite zapiski, wśród których: "legista i.e. iurista-prawnik". W Glossarium ukończonem reką zakonnika w Miechowie, Juliana z Kruchowa: "Juliani de Cruchowo fratris religiosi in Myechow", w 1455, roku. (A 1. B r ü ckner: Neue Quellen zur Geschichte: Archiv für slavische Philologie. v. Jagić. Berlin. XIV. 496.): „prolocutor", określony jako „prawnyk”.

Marcin Bielski w ,Kronice Swiata”, opisując czasy zamieszek religijnych $\mathrm{w}$ Niemczech, wyrazil się; 221. r.: ,A ludzie wielkie uczone, a w prawie biegłe";... (Ferdynand do Książąt) bronić taż prawa nie może... Książęciu Brunszwickiemu, któregoście z imienia wygnali".

\section{Prawny tj. oznaczony prawem dzień}

W mamotrekcie (tj. objas̊nieniu znaczenia danego slowa potocznym językiem) pochodzącym z 1471 roku. (Jan Eoś: Materiały i Prace Kom. Językowej A.U. V. 65.): ,pravni-in actum”.

W zapisce sądu grodzkiego przemyskiego z 1498, roku. (Akta Grodzkie u Ziemskie z czasów Rzpltej Polskiej z Archiwum Bernardyńskiego we Lwowie. r. 1868. T. XVIII. 387.: Najdawniejsze zapiski sądu 
grodzkiego przemyskiego.): „Iste Gyan (tj. Jan) venerat... super diem positum iuri alias pravni posuerat".

Prawo w znaczeniu prawowitego majątku i ius radicale, korzenne prawo

Wiadomość z sądu wielkopolskiego z 1407, roku. (F r a n c is z ek Piekosiński: Wybór zapisek sądowych grodzkich i ziemskich wielkopolskich z XV, wieku: Studia, Rozprawy i Materialy z Dziedziny Historyi Polskiej. VI. 319.): „Bninscy chczeli prawo Tarnowskyego kmeczem ossadzicz, a on ne zdayądz prawa przeprosszil gich (ich)", czyli nie ustępując majątku.

W zapiskach sądowych mazowieckich $z$ 1497, roku. (J. K. K ochanowski: Próba ujęcia hermeneutycznego pojęcia o ziemi i obyczaju, księciu i przywileju w świetle praktyki sądowej na Mazowszu u schyłku wieków średnich: Sprawozd. z Posiedzeń Tow. Nauk. Warszawskiego. VIII. 2. 27,), znajdujemy wyrażenie "Ius radicale super bona, prawo corzenne na ymienie", czyli korzenne do imienia, tj. majątku.

\section{Praworządny}

Wiadomośc z 1443, roku z zapisków sądowych ziemskich warszawskich (Zapiski i roty polskie XV-XVI wieku z ksiąg sądowych ziemI warszawskiej. wyd. Wladysław Kuraszkiewicz i Adam Wolff. P.A.U. 1950. Prace Kom. Jęz. Nr. 730.): „Jaco (jako) mnye micolay (Mikolaj) nechczał uczinicz prawa srzadnym parophem czsom gy gual (mial) u nego we wsy. Jakom ya byl przitem nicolay nechczal uczinicz prawa szradnim paropkem ciso gy gual u nego we wsy".

\section{Prawo w znaczeniu umowy prawnej}

W Skrzyszowie w Tarnowskim dwaj wieśniacy zawierając umowę mówią, że to prawo: „Prawa... zaprosili, aby Prawo wysłuchało Rodzica i Zapisu” („Lud”. XIII. 254.).

Prawo w znaczeniu przyrzeczenla danego słowa

We wsi Eosienica, w sieradzkim powiecie, mówią: „Jakzem cle zwionzała, tak prawa dotrzymam".

„Na prawle" w znaczeniu na prawde

Spiewają kolo Bytomia (Pieśni wyd. P.A.U. I 111): 
„Powiedz mi na prawie

Powiedz mi na razie

Niech moje koniki

Nie stoją na mrozie".

\section{Prawo $\mathrm{W}$ znaczeniu sposobu}

Z Bukowa Olkuskiego: „Kieby go jakiem prawem ukraść, aby pogrzeb sprawić". (K. Nits ch: Wybór tekstów gwarowych. jow. str. 89. Nr. 94.). Z Poręby Wielkiej, czyli Niedźwiedzia nad Mszaną: „I taKim prawem sfiec (tj. szewc) se zakrojuń rozumu, bo zonie podarowàu, bo nalaz guupse stworzenie, iag jego zona". (E dward Klich: Mater.Etnogr. z polud.-zachod. częśsi powiatu limanowskiego. Teksty gwarowe. Mater. Antrop.-Archeol. i Etnogr. A.U. XI. 34.).

\section{Miejscowości}

Z miejscowości, które moglyby pochodzić od zajmującego nas tu słowa, to Prawo, wieś nad rzeką Stróżą w powiecie puławskim, w pierwszej połowie XIX wieku była jeszcze miasteczkiem. Prawęcice, niegdyś własność opactwa w Trzemesznie, w powiecie łęczyckim, wymienione w Liber Beneficiorum Easkiego (II. 377.) jako Praveczice. Znów Prawęcin w powiecie opatowskim, w parafii Kunów, wśród wzgórz Swiętokrzyskich, uzyskalo prawo średzkie do Kazimierza Wielkiego w 1340 roku, na prośbę właścicielki Jadwigi, wdowy po Brosz$\mathrm{ku}, z$ jej synami. Miejscowość tę zbudowano $w$ dąbrowie, zwanej też Prawęcin, a wedle regestru poboru województwa sandomierskiego z 1578. roku, była ona już wlasnością benedyktyńskiego opactwa świętokrzyskiego. Prawielniki wieś nad Bystrzycą $w$ powiecie lubelskim, wspomniana $w$ Liber Beneficiorum Dlugosza (II. 540.), jak i w regestrach poborowych powiatu lubelskiego w 1531 r. Prawocice, wies w trzebnickim powiecie, po niemiecku przezwano Probotschütz, a nastepnie Wiesenbrunn. Prawociny, we wrocławskim powiecie przezwany Probotschine, a następnie Probstaue. Można domyśleć się, że nazwy powstały od procesowania się o własność ziemi, na której powstaly, czy też już $z$ powodu sporu o same te osady. 